OPEN ACCESS

Edited by:

Vita Dolzan,

University of Ljubljana, Slovenia

Reviewed by:

Vijay Suppiah,

University of South Australia, Australia

Ursula Amstutz,

University of Bern, Switzerland

*Correspondence:

Henk-Jan Guchelaar

H.J.Guchelaar@/umc.nI

Specialty section: This article was submitted to

Pharmacogenetics and

Pharmacogenomics,

a section of the journal

Frontiers in Pharmacology

Received: 29 May 2020

Accepted: 25 August 2020 Published: 23 September 2020

Citation:

Manson LEN, Swen JJ and Guchelaar H-J (2020) Diagnostic Test Criteria for HLA Genotyping to Prevent Drug Hypersensitivity Reactions: A Systematic Review of Actionable HLA

Recommendations in CPIC and DPWG Guidelines.

Front. Pharmacol. 11:567048. doi: 10.3389/fphar.2020.567048

\section{Diagnostic Test Criteria for HLA Genotyping to Prevent Drug Hypersensitivity Reactions: A Systematic Review of Actionable HLA Recommendations in CPIC and DPWG Guidelines}

\author{
Lisanne E. N. Manson ${ }^{1,2}$, Jesse J. Swen ${ }^{1,2}$ and Henk-Jan Guchelaar ${ }^{1,2 *}$ \\ ${ }^{1}$ Department of Clinical Pharmacy \& Toxicology, Leiden University Medical Center, Leiden, Netherlands, ${ }^{2}$ Leiden Network for \\ Personalized Therapeutics, Leiden, Netherlands
}

Introduction: Certain HLA variants are associated with an increased risk of hypersensitivity reactions to specific drugs. Both the Clinical Pharmacogenetics Implementation Consortium (CPIC) and the Dutch Pharmacogenetics Working Group (DPWG) have issued actionable HLA gene - drug interaction guidelines but diagnostic test criteria remain largely unknown. We present an overview of the diagnostic test criteria of the actionable HLA - drug pairs.

Methods: A systematic literature search was conducted in PubMed, Embase, Web of Science and Cochrane Library. Original case-control and cohort studies were selected and sensitivity, specificity, positive predictive value (PPV), negative predictive value (NPV) and number needed to genotype (NNG) were calculated for the actionable HレA-drug pairs.

Results: In general, the HLA tests show high specificity and NPV for predicting hypersensitivity reactions. The sensitivity of HLA tests shows a wide range, from 0-33\% for HLA-B*1502 testing to predict lamotrigine induced SJS/TEN up to 100\% for HLA$B^{\star} 5701$ to predict immunologically confirmed abacavir hypersensitivity syndrome (ABCHSR). PPV is low for all tests except for HLA-B*5701 and ABC-HSR which is approximately $50 \%$. HLA-B*5701 to predict ABC-HSR shows the lowest NNG followed by HLA-B*5801 for allopurinol induced severe cutaneous adverse drug reactions and HLA-B*1502 for carbamazepine induced SJS/TEN.

Discussion: This is the first overview of diagnostic test criteria for actionable HLA-drug pairs. Studies researching HLA genes and hypersensitivity are scarce for some of the HLA-drug pairs in some populations and patient numbers in studies are small. Therefore, more research is necessary to calculate the diagnostic test criteria more accurately.

Keywords: HLA genes, pharmacogenomics, hypersensitivity, antiepileptic drugs, abacavir, allopurinol, flucloxacillin 


\section{INTRODUCTION}

Adverse drug reactions (ADRs) are an important cause of hospitalization and mortality in modern healthcare. ADRs can be classified as type A or type B. Type A reactions are often common and can be predicted from the drug's pharmacological mechanism of action. Type $B$ reactions, also known as idiosyncratic or hypersensitivity reactions, are usually much rarer and unpredictable and therefore pose a serious risk for patients as they can even be life-threatening.

The hypersensitivity reactions included in this review are: Stevens-Johnson syndrome (SJS) and toxic epidermal necrolysis (TEN), drug reaction with eosinophilia and systemic symptoms (DRESS), maculopapular exanthema (MPE), abacavir hypersensitivity syndrome (ABC-HSR) and drug-induced liver injury (DILI).

Stevens-Johnson syndrome (SJS) and toxic epidermal necrolysis (TEN) are the most serious types of severe cutaneous adverse drug reaction (SCAR). Both SIS and TEN are characterized by fever and mucocutaneous lesions leading to necrosis and sloughing of the epidermis. The two diseases are separated based on the percentage of body surface area detached: $1 \%-10 \%$ detachment defines SJS, 10\%-30\% detachment defines SJS/TEN overlap, and $>30 \%$ detachment defines TEN. The mortality of SIS/ TEN is estimated to be approximately $25 \%$, ranging from $5 \%-10 \%$ for SJS to more than 30\% for TEN (Sekula et al., 2013; Mahar et al., 2014; High, 2020; Mockenhaupt, 2020).

Drug reaction with eosinophilia and systemic symptoms (DRESS), also belonging to the term SCAR, describes a potentially life-threatening syndrome including a severe skin eruption, fever, hematologic abnormalities and involvement of internal organs. The mortality of DRESS is estimated to be about 5\%-10\% (Chen et al., 2010; Cacoub et al., 2011; Mockenhaupt, 2020). Another term used for DRESS is drug-induced hypersensitivity syndrome (DIHS).

Maculopapular exanthema (MPE) is a milder form of cutaneous ADR. It is the most common type of cutaneous ADR, occurring in approximately 2 percent of individuals exposed to drugs. MPE is characterized by erythematous macules and papules. Systemic symptoms include pruritus, low-grade fever, and mild eosinophilia. Usually the rash develops 5 to 14 days after starting treatment, but it may occur within one or two days. The rash usually improves within 2 weeks after withdrawal of the culprit drug.

Abacavir hypersensitivity (ABC-HSR) has several similar features as DRESS but does not have all the major criteria for DRESS. ABC-HSR is usually a combination of symptoms: Fever is almost always present and patients also often suffer from dizziness, headache, malaise and gastrointestinal symptoms. Respiratory symptoms and rash can be present as well. In the early use of abacavir, ABC-HSR became the main reason for drug discontinuation in approximately 8 percent of treated patients (Symonds et al., 2002; Young et al., 2008; Elizabeth J Phillips, 2020).

Drug-induced liver injury (DILI) is rare and has an estimated annual incidence between 10 and 15 per 10,000 to 100,000 persons exposed to prescription medications. Acute presentations of DILI include mild, asymptomatic liver test abnormalities but also liver failure. DILI accounts for approximately 10 percent of all cases of acute hepatitis. DILI is also a frequent reason for withdrawal of medications from the market (Larson, 2020).

The discovery of the first ADR-HLA genotype association, HLA-B $^{\star} 5701$ associated with abacavir hypersensitivity, and its mandatory testing as obliged in the drug label initiated a whole new field of research leading to additional significant HLAvariant - ADR associations in the last decade.

Both the Clinical Pharmacogenetics Implementation Consortium (CPIC) and the Dutch Pharmacogenetics Working Group (DPWG) have issued actionable HLA gene - drug interaction guidelines. The HLA-drug pairs considered as actionable by CPIC and/or DPWG are: HLA-B ${ }^{\star 5701-a b a c a v i r, ~ H L A-B}{ }^{\star} 5701$-flucloxacillin, HLA-B ${ }^{\star 5801-}$ allopurinol, HLA-A ${ }^{\star} 3101$-carbamazepine, HLA-B ${ }^{\star} 1511$ carbamazepine, HLA-B ${ }^{\star} 1502$-carbamazepine, HLA-B ${ }^{\star} 1502$ oxcarbazepine, HLA-B ${ }^{\star} 1502$-lamotrigine and HLA- $B^{\star} 1502$-phenytoin.

These guidelines are based upon different types of studies including case-control studies and cohort studies. While there is evidence for the association between HLA variants and the occurrence of ADRs, HLA testing is not yet being performed pre-emptively, except for HLA-B ${ }^{\star} 5701$ and abacavir and HLA$\mathrm{B}^{\star} 1502$ and carbamazepine in some Asian populations. Preemptively testing HLA-A $A^{\star 3101}$ is recommended by the Canadian and Swiss drug label for some populations but it is not mandatory, We hypothesize that an important reason for a lack of implementation of pre-emptive HLA testing is the fact that diagnostic test criteria for the tests remain largely unknown. We have found one other review with an overview of diagnostic test criteria but this study has focused on antiepileptic drugs only and not on all drugs with actionable HLA gene - drug interactions (Mullan et al., 2019).

Therefore, we aim to present an overview of the diagnostic test criteria, namely the sensitivity, specificity, positive predictive value (PPV), negative predictive value (NPV) and the number needed to genotype (NNG) for all actionable HLA - drug pairs.

\section{METHODS}

We conducted a systematic literature search in PubMed, Embase, Web of Science and the Cochrane Library for case-control studies and prospective and retrospective cohort studies that evaluated known HLA - ADR associations. Based on the CPIC and DPWG guidelines for actionable HLA-drug pairs we restricted our search to articles concerning abacavir, allopurinol, flucloxacillin, carbamazepine, oxcarbazepine, lamotrigine and phenytoin. Search terms consisted of "drug name" AND drug hypersensitivity AND HLA and included synonyms of these terms (see Supplementary File 1). Records were screened on title and abstract. Duplicates, comments, editorials, narrative reviews, letters without original data and publications in languages other than English were excluded. Papers reporting original data with a minimum of 40 patients of which at least 10 hypersensitivity cases in total were included. We selected only studies where the HLA variants were genotyped directly. Studies that used a variant in linkage with the causal HLA variant were excluded since linkage 
disequilibrium is not known for all populations and shows considerable variation. We only selected studies where tolerant controls were available to calculate the diagnostic test criteria most accurately. All diagnostic test criteria were calculated by using the tolerant controls data while the population controls, if available, were used to calculate allele carrier frequencies in the general population. Calculation of sensitivity, specificity, PPV, NPV and NNG were done according to Tonk et al., and Steinberg et al. (Steinberg et al., 2009; Tonk et al., 2017) using the data described in the original articles. Considered endpoints included SCAR, SJS/ TEN, DRESS, MPE, ABC-HSR and DILI. The endpoints used in the calculation of the diagnostic test criteria are similar to the endpoints mentioned in the specific CPIC and DPWG guidelines. For instance when the CPIC and/or DPWG guidelines only mention an association with SJS/TEN, other endpoints are not included in the results section.

To calculate the NPV, PPV and NNG, the incidence of the $\mathrm{ADR}$ is required. However, the incidence is not always available. Therefore we extracted the incidence from literature in one of the following ways and in this order:

i. Directly from the included article itself when the article is a cohort study

ii. From the DPWG or CPIC guideline based on a review, meta-analysis or original article

iii. Derived from an original article in a similar population

In the tables in the result section, the source used for the incidence is mentioned.

\section{RESULTS}

\section{Study Selection}

Figure 1 shows the result of the study selection. Initially, 1,383 publications were identified. The publications were first screened by title and abstract and then the full-text articles were assessed for eligibility. In total, 69 studies matched the inclusion criteria for analysis in this systematic review. Of these 69 studies, only the 56 studies investigating the same endpoints as the CPIC and/ or DPWG guidelines and having the data needed for calculating the diagnostic test criteria were used in the Results section of this systematic review.

\section{Abacavir}

Abacavir is a nucleoside analog reverse-transcriptase inhibitor (NRTI) used to treat and prevent HIV and is always used in combination with other antiretroviral drugs. To date, it is the only drug for which a pre-emptive HLA test is mandatory according to the drug label. Abacavir is contraindicated for patients who have been tested positive for the HLA-B ${ }^{\star} 5701$ variant or for patients who have not been tested because a positive test result is strongly associated with abacavir hypersensitivity syndrome (ABC-HSR) (Koninklijke Nederlandse Maatschappij ter bevordering der Pharmacie, 2020a). ABC-HSR occurs in $4 \%-8 \%$ of patients receiving abacavir prior to implementation of pre-emptive HLA-B ${ }^{\star} 5701$ testing
(Hetherington et al., 2001; Mallal et al., 2008). The incidence of ABC-HSR seems to be much higher in Caucasian populations due to a higher frequency of the HLA-B ${ }^{\star} 5701$ allele than in nonCaucasian populations (To et al., 2013; Zhang H. et al., 2015; Youssoufi et al., 2017; Agbaji et al., 2019).

We have identified nine articles that met our inclusion criteria, all but one only in Caucasians. The results are summarized in Table $\mathbf{1}$ for clinically diagnosed ABC-HSR and in Table 2 for immunologically confirmed ABC-HSR.

Almost all the included studies were performed in Caucasians but the reported incidence of abacavir hypersensitivity differs between the studies. Therefore different incidences (1.4\%-9.0\% for Caucasian populations) are used for calculating the PPV, NPV, and NNG.

The specificity of the HLA-B ${ }^{\star} 5701$ test is high in all studies: 90 $100 \%$, as is the NPV: $95 \%-100 \%$ in clinically diagnosed and $100 \%$ in immunologically confirmed subjects. The sensitivity of the HLA$B \star 5701$ test for abacavir HSR differs greatly between the studies and is between $31 \%$ and $90 \%$ for clinically diagnosed Caucasian patients. However, for immunologically confirmed HSR the sensitivity increases to $100 \%$. The PPV is around $50 \%$. The number of new abacavir users needed to genotype to prevent one case of ABC-HSR is 14-90 in Caucasians but 10 times higher in Blacks.

\section{Allopurinol}

Allopurinol is the most commonly used drug for the treatment of gout and hyperuricemia. However, a great safety concern of allopurinol is the risk of SCAR which is estimated to be $0.1 \%$ $0.4 \%$ among new users. (Hershfield et al., 2013) It has been proven that HLA-B ${ }^{\star} 58: 01$ is associated with an increased risk for allopurinol induced SCAR. Nineteen studies are identified using the inclusion criteria described in the methods. Of these 19 studies, 14 are included in the results tables whereas the others investigated other endpoints or did not genotype cases and tolerant controls. The results of the HLA-B ${ }^{\star} 5801$ test criteria are shown in Table 3 for SCAR, Table 4 for DRESS, and Table 5 for SJS-TEN.

The incidence of SCAR is $0.1 \%-0.4 \%$ according to the CPIC guideline (Hershfield et al., 2013). Based on the results of a PubMed search the incidence of SJS/TEN is estimated to be $0.16 \%$ for SJS/TEN and $0.05 \%$ for DRESS (Sunicha Limkobpaiboon and Naruemon Dhana, 2010; Saokaew et al., 2014; Chong et al., 2018). Thus we use an incidence of $0.21 \%$ for SCAR (Min et al., 2015; Ke et al., 2019; Lin et al., 2019).

HLA-B ${ }^{\star} 5801$ testing in Asian populations shows high sensitivity and high specificity for allopurinol induced SCAR: $88 \%-100 \%$ and $82 \%-94 \%$ respectively. The only identified study in a non-Asian population, a Portuguese population, shows a lower sensitivity of $64 \%$ but a high specificity of $94 \%$. The PPV is low $(1.1 \%-3.0 \%)$ while the NPV is approximately 1 . The frequency of carriers of the HLA-B ${ }^{\star} 5801$ allele is lower in the Portuguese population than in Asian populations (4\% versus $10 \%-20 \%$ respectively). If HLA$\mathrm{B}^{\star 5801}$ is the only SNP associated with allopurinol induced SJS/ TEN, the incidence of SCAR in this population is expected to be lower, leading to a higher NNG. In the Portuguese population also other HLA variants may be of importance. The calculated NNG for SCAR is 476-540 in Asian populations and is assumed to be much higher in the Portuguese population and other populations with a lower frequency of the HLA-B ${ }^{\star} 5801$ allele. 


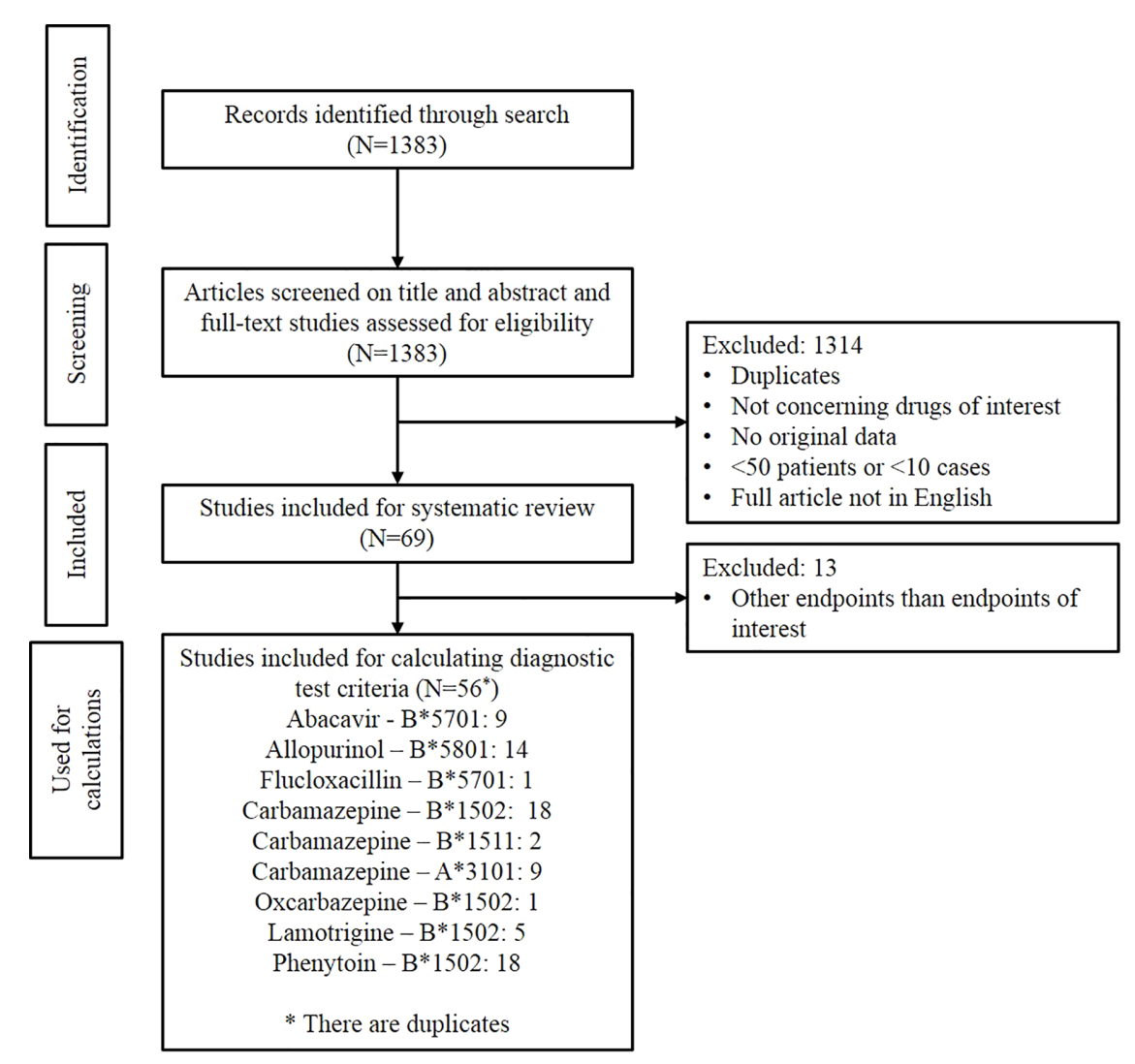

FIGURE 1 | Study flow diagram of the systematic review inclusion.

The high sensitivity and specificity are seen for both SJS/TEN and DRESS, as shown in Table 4 (DRESS) and Table 5 (SJS/TEN).

Sensitivity and specificity for the HLA-B ${ }^{\star} 5801$ test for allopurinol induced DRESS and SJS/TEN are comparable to the numbers mentioned above for SCAR. Sensitivity for allopurinol induced DRESS and SJS/TEN is $91.7 \%-100 \%$ and $80.0 \%-100 \%$ respectively in Asians. Specificity is between $82.1 \%$ and $96.0 \%$. Due to the low incidence of allopurinol induced DRESS the NNG to prevent one case of DRESS is 2,000-2,182 in Asian populations. The NNG for allopurinol induced SJS/TEN is 625-781 in Asian populations.

\section{Flucloxacillin}

Flucloxacillin is a penicillin antibiotic used for treating infections caused by Gram-positive bacteria such as staphylococci or streptococci. Although extremely rare, flucloxacillin has been associated with drug-induced liver injury (DILI). DILI is a collective term of different liver injuries as adverse drug reactions (ADRs) due to various drugs. The drug label of flucloxacillin mentions a clear correlation between HLA-B ${ }^{\star} 5701$ and flucloxacillin-induced liver damage but does not advise routine pre-emptive testing due to the rarity of DILI and the low PPV of 0.12\% (Aurobindo Pharma, 2019). The incidence of DILI is estimated to be about $8.5 / 100,000$ in new flucloxacillin users (Russmann et al., 2005). The DPWG has issued recommendations for HLA-B`5701 and flucloxacillin induced DILI. The recommendations indicate to monitor liver function more regularly and switch to an alternative when liver enzymes or bilirubin increase (Koninklijke Nederlandse Maatschappij ter bevordering der Pharmacie, 2020b). The CPIC however has not defined an actionable guideline about this drug-gene interaction.

Only one article is identified meeting our inclusion criteria. The results are shown in Table 6.

The HLA-B ${ }^{\star} 5701$ test has relatively high sensitivity and specificity ( $84.3 \%$ and $93.8 \%$ respectively) for flucloxacillin induced DILI. However, due to the rarity of flucloxacillin induced DILI, the test has a very low PPV of $0.11 \%$ and high NPV (99.99\%). The low incidence of DILI results in a high NNG for DILI of 13,953.

\section{Antiepileptic Drugs}

Epilepsy is one of the most common chronic neurological disorders affecting millions of people worldwide. Many epileptic people use antiepileptic drugs (AEDs) to treat their condition. But these AEDs, especially carbamazepine, oxcarbazepine, phenytoin and lamotrigine are, along with allopurinol, the most common cause of cutaneous adverse drug reactions (cADRs) including the previously mentioned severe SJS/TEN and DRESS but also a milder form of cADR called macopapular exanthema (MPE). Carbamazepine, oxcarbazepine, lamotrigine and phenytoin induced cADRs are associated with HLA- ${ }^{\star} 1502$ (Koninklijke Nederlandse Maatschappij ter bevordering der Pharmacie, 2020c; 


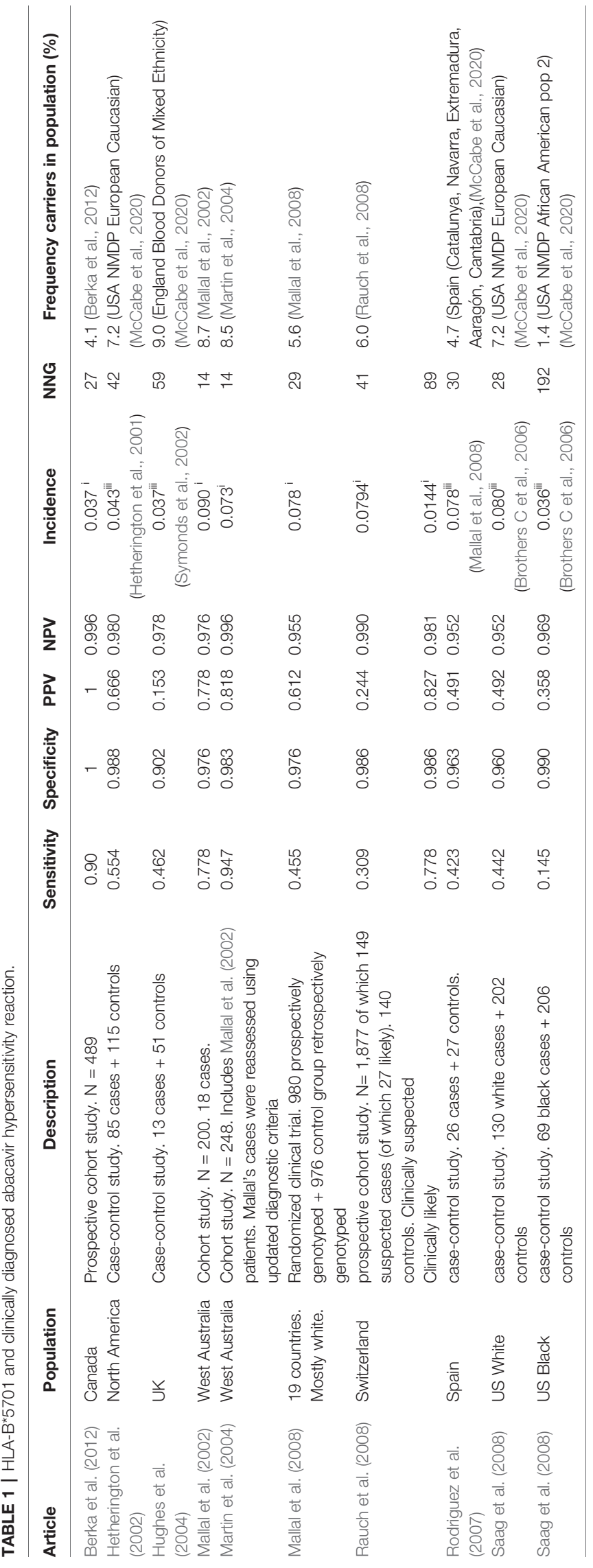

Koninklijke Nederlandse Maatschappij ter bevordering der Pharmacie, 2020d; Koninklijke Nederlandse Maatschappij ter bevordering der Pharmacie, 2020e; Koninklijke Nederlandse Maatschappij ter bevordering der Pharmacie, 2020f). For carbamazepine induced cADRs also associations with HLA$B^{\star} 1511$ and HLA- $A^{\star} 3101$ have been shown.

There is evidence of cross-sensitivity among the AEDs carbamazepine, oxcarbazepine, lamotrigine and phenytoin (Bloch et al., 2014). In a Norwegian retrospective study of medical records it was found that phenytoin, carbamazepine and oxcarbazepine caused rashes in $27 \%-35 \%$ of patients with a history of another AED related rash (Alvestad et al., 2008). Lamotrigine was with 17\% less involved in cross-sensitivity than carbamazepine, oxcarbazepine and phenytoin. A retrospective study of medical records in China also found high cross-sensitivity rates between the four AEDs, especially when carbamazepine and phenytoin were involved (Wang et al., 2010). There was a highly significant mutual risk for cross-sensitivity for CBZ and PHT, and OXC, and LTG. The substantial evidence for cross-sensitivity means caution is needed when prescribing these AEDs, especially when switching from one of these AEDs to another due to an cADR.

\section{Carbamazepine}

Carbamazepine is a widely used drug approved for the treatment of epilepsy, bipolar disorder and neuropathic pain. It is however known to be able to cause cADRs. Associations have been shown between HLA-B ${ }^{\star} 1502$ in Asian populations and SJS/TEN (Leckband et al., 2013; Koninklijke Nederlandse Maatschappij ter bevordering der Pharmacie, 2020c). Also in some populations HLA-B* 1511 has been shown to be associated with SJS/TEN (Kim et al., 2011; Shi et al., 2012). In contrast, in European and Japanese populations not HLA$B$ alleles but HLA- $A^{\star 3101}$ has been shown to be associated with SJS/ TEN. This variant has also been shown to be associated with DRESS and MPE. The DPWG does not give an actionable advice on MPE, but the CPIC guideline on the other hand does state that an HLA$\mathrm{A}^{*} 3101$ positive carbamazepine user has a higher chance of MPE as well as SJS/TEN and DRESS. In the drug label HLA-B ${ }^{\star} 1502$ and HLA- $A^{\star} 3101$ testing is advised in high risk patients. Patients are deemed to be at risk when they come from countries with a high prevalence of the HLA-B*1502 allele such as Hong Kong, Thailand, Taiwan, Malaysia, and parts of the Philippines. The drug label states the use of carbamazepine and other AEDs associated with SJS/TEN should be avoided in patients who test positive for the HLA-A $A^{\star} 3101$ or HLA-B*1502 alleles (ULC MP, 2015). The CPIC's advice is the same whereas the DPWG guideline also advises to consider an alternative in HLA-B ${ }^{\star} 1511$ positive patients (Hershfield et al., 2013; Koninklijke Nederlandse Maatschappij ter bevordering der Pharmacie, 2020c). The Swiss and Canadian drug label strongly recommend testing HLA-A ${ }^{\star} 3101$ in high risk populations. The Swiss label considers Japanese, Caucasians, American indigenous population and patients of Spanish, Portuguese, South Indian and Arabic ancestry to be at high risk.

The incidence of SJS/TEN is $0.005 \%$ in European Caucasian populations (Genin et al., 2014; Koninklijke Nederlandse Maatschappij ter bevordering der Pharmacie, 2020c) and in Chinese and other some Asian populations it is $0.25 \%$ (Genin et al., 2014; Koninklijke Nederlandse Maatschappij ter bevordering 
TABLE 2 | HLA-B`5701 and immunologically confirmed abacavir hypersensitivity reaction.

\begin{tabular}{|c|c|c|c|c|c|c|c|c|c|}
\hline Article & Population & Description & Sensitivity & Specificity & PPV & NPV & Incidence & NNG & $\begin{array}{l}\text { Frequency carriers in } \\
\text { population (\%) }\end{array}$ \\
\hline Mallal et al. (2008) & $\begin{array}{l}19 \\
\text { countries. } \\
\text { Mostly } \\
\text { white. }\end{array}$ & $\begin{array}{l}\text { Randomized clinical trial. } 980 \\
\text { prospectively genotyped. } 976 \text { control } \\
\text { group (retrospectively genotyped) }\end{array}$ & 1 & 0.969 & 0.479 & 1 & $0.027^{i}$ & 37 & 5.6 (Mallal et al., 2008) \\
\hline Saag et al. (2008) & US White & $\begin{array}{l}\text { Case control study. } 130 \text { white cases + } \\
202 \text { controls }\end{array}$ & 1 & 0.960 & 0.406 & 1 & $\begin{array}{c}\text { 0.026, } \\
\text { (Brothers C } \\
\text { et al., 2006) }\end{array}$ & 38 & $\begin{array}{l}7.2 \text { (USA NMDP } \\
\text { European Caucasian) } \\
\text { (McCabe et al., 2020) }\end{array}$ \\
\hline Saag et al. (2008) & US. Black & $\begin{array}{l}\text { Case-control study. } 69 \text { black cases }+ \\
206 \text { controls }\end{array}$ & 1 & 0.990 & 0.206 & 1 & $\begin{array}{l}0.0025 \text { i,iii } \\
\text { (Brothers C } \\
\text { et al., 2006) }\end{array}$ & 397 & $\begin{array}{l}1.4 \text { (USA NMDP African } \\
\text { American pop 2) } \\
\text { (McCabe et al., 2020) }\end{array}$ \\
\hline
\end{tabular}

der Pharmacie, 2020c). To be able to calculate NPV, PPV and NNG for other Asian populations such as Vietnamese and Malaysian, an incidence of $0.25 \%$ is assumed. The incidence of SJS/TEN in nonEuropean Caucasians is assumed to be $0.005 \%$.

The results of studies studying the association of HLA-B ${ }^{\star} 1502$ and carbamazepine induced SJS/TEN are summarized in Table 7.

In general, studies find a relatively high sensitivity (67-100\%) and specificity (73-100\%) for HLA-B ${ }^{\star} 1502$ and carbamazepine induced SJS/TEN. However in some populations such as Korean, Canadians of diverse ancestry, Indonesian, North east Chinese and Indians in Malaysia lower sensitivities of $14-57 \%$ are found (Kim et al., 2011; Amstutz et al., 2013; He et al., 2013; Khor et al., 2017; Khosama et al., 2017). In these populations, the allele frequency is lower than in the other Asian populations which may indicate that in these populations also other HLA variants may be of importance, for instance the HLA-A ${ }^{\star} 3101$ or HLA$B^{\star} 1511$ variants. In the study from Genin et al. the sensitivity in Europeans is zero and the specificity is $100 \%$ since there were no Europeans positive for HLA-B ${ }^{\star} 1502$ in this study.

Due to the low incidence, the PPV is low $(0.14 \%-7.8 \%)$ while the NPV is high (99.2\%-100\%). The NNG is $400-2,800$ in Asian populations of which most studies lead to a NNG of 400-700. In Canadians, the NNG is 60,000 .

Studies about the association of carbamazepine induced SJS/ TEN and HLA-B ${ }^{\star} 1511$ are scarce. Only two studies meet our inclusion criteria. See Table 8.

In southern Han Chinese, the HLA-B ${ }^{\star} 1511$ test shows very low sensitivity (7.1\%) for carbamazepine induced SJS/TEN. In a Korean population the sensitivity is higher but still low (42.9\%). The low sensitivity in southern Han Chinese can be explained by the low allele frequency of HLA-B ${ }^{\star} 1511$ in this population $(0.4 \%)$. The low sensitivity indicates that testing only HLA-B ${ }^{\star} 1511$ in carbamazepine initiators might be insufficient to predict SJS/TEN, because of the influence of other HLA-genes such as HLA-B ${ }^{\star} 1502$. Specificity in both studies is high and so is the NPV. The PPV is low. The NNG in the study by Kim et al. is 933 while in the study among Southern Han Chinese from Shi et al. it is 5,600 (Kim et al., 2011; Shi et al., 2012).

The results of carbamazepine induced SJS/TEN and HLA$A^{\star} 3101$ are summarized in Table 9.

HLA-A ${ }^{\star} 3101$ testing shows high specificity $(86.0 \%-96.7 \%)$ but mostly low sensitivity $(0.0 \%-83.3 \%)$ for carbamazepine induced SJS/TEN. Only in Japanese, Korean and Indian Malaysian relatively high sensitivities are found $(42.9 \%-83.3 \%)$. The PPV is $0 \%-1.6 \%$ while the NPV is close to $100.0 \%$ in all studies. The NNG shows a high variability and is between 480 and 133,333.

The results of carbamazepine induced DRESS and HLA$A^{\star} 3101$ are summarized in Table 10. The incidence of DRESS is assumed to be $0.05 \%$ in both Asian and Caucasian populations (Koninklijke Nederlandse Maatschappij ter bevordering der Pharmacie, 2020c).

Sensitivity for HLA-A*3101 and carbamazepine induced DRESS is about $50 \%$ in several populations $(30.4 \%-70.0 \%)$ while specificity is high $(86 \%-97 \%)$. The exception is the study by Ihtisham et al. with a sensitivity of 0 . However, this study only had two DRESS cases which both did not carry the HLA-A 3101 allele Ihtisham et al. (2019). The NNG is high in all studies (2,857-6,571).

The results of HLA-A ${ }^{\star} 3101$ and carbamazepine induced MPE are summarized in Table 11. The incidence of MPE is assumed to be $10 \%$ in Caucasian users and $4.4 \%$ in Chinese and other Asian users (Koninklijke Nederlandse Maatschappij ter bevordering der Pharmacie, 2020c).

Sensitivity for HLA-A ${ }^{\star 3101}$ and carbamazepine induced MPE is low (1\%-23\%). The sensitivity is higher in Europeans, Canadians of mixed ethnicities and Indian populations than in Chinese populations. Specificity is high in all populations (94\%-99\%). PPV is low $(3 \%-44 \%)$ while NPV is consistently high (91\%-98\%). Due to the high incidence of MPE, the NNG is low, especially in Canadians and Europeans (Locharernkul et al., 2008; GlaxoSmithKline, 2009; US Food and Drug Administration, 2009; He et al., 2012; Shi et al., 2012; Amstutz et al., 2013; He et al., 2013; Lv et al., 2013; Caudle et al., 2014; Genin et al., 2014; ULC MP, 2015; Moon et al., 2016; Pfizer, 2016; Chen et al., 2017; Khor et al., 2017; Khosama et al., 2017; Deng et al., 2018; Fowler et al., 2019). But NNG is also low in North India (An et al., 2010) due to a relatively high sensitivity (22.2\%). In the other study populations NNG is 166-1818.

\section{Oxcarbazepine}

Oxcarbazepine is an AED structurally related to carbamazepine. Therefore it might not be surprising that there is also evidence of an association of HLA-B ${ }^{\star} 1502$ and oxcarbazepine induced SJS/TEN leading to CPIC and DPWG guidelines about this association (Leckband et al., 2013; Koninklijke Nederlandse Maatschappij ter bevordering der Pharmacie, 2020e). The drug label of oxcarbazepine warns to only use the drug in HLA-B ${ }^{\star} 1502$ positive patients when the benefits clearly outweigh the risk (US Food and Drug Administration, 2009). 
TABLE 3 | HLA-B5801 and allopurinol induced severe cutaneous adverse drug reaction (SCAR).

\begin{tabular}{|c|c|c|c|c|c|c|c|c|c|}
\hline Article & Population & Description & Sensitivity & Specificity & PPV & NPV & Incidence ${ }^{\mathrm{ii}, \mathrm{iii}}$ & NNG & Frequency carriers in population (\%) \\
\hline Chen et al. (2015) & Eastern China & $\begin{array}{l}17 \text { SCAR cases }+31 \text { tolerant controls } \\
+120 \text { population controls }\end{array}$ & 0.882 & 0.935 & 0.0280 & 0.9997 & 0.0021 & 540 & 14.2 (Chen et al., 2015) \\
\hline Cheng et al. (2015) & Han Chinese & $\begin{array}{l}92 \text { SCAR cases }+75 \text { tolerant controls } \\
+99 \text { population controls }\end{array}$ & 0.946 & 0.880 & 0.0163 & 0.9999 & 0.0021 & 504 & 10.1 (Cheng et al., 2015) \\
\hline Zhang X. et al. (2015) & Han Chinese & $\begin{array}{l}48 \text { SCAR cases }+133 \text { controls }+280 \\
\text { population controls }\end{array}$ & 0.938 & 0.925 & 0.0256 & 0.9999 & 0.0021 & 508 & 12.1 (Zhang X. et al., 2015) \\
\hline Chiu et al. (2012) & Hong Kong Han Chinese & 19 SCAR cases +30 controls & 1 & 0.867 & 0.0155 & 1 & 0.0021 & 476 & 14.2 (Hong Kong Chinese) (McCabe et al., 2020) \\
\hline Jung et al. 2011) & Korea & $\begin{array}{l}\text { Retrospective cohort study. } \mathrm{N}=448.9 \\
\text { cases. }\end{array}$ & 1 & 0.905 & 0.0217 & 1 & 0.0021 & 476 & 12.2 (Jung et al., 2011) \\
\hline Kang et al. (2011) & Korea & 26 SCAR cases +57 controls & 0.923 & 0.895 & 0.0181 & 0.9998 & 0.0021 & 516 & 11.8 (South Korea pop 10) (McCabe et al., 2020) \\
\hline Gonçalo et al. (2013) & Portugal & 25 SCAR cases +23 controls & 0.640 & 0.957 & 0.0300 & 0.9992 & 0.0021 & 744 & 4.0 (Portugal Center) (McCabe et al., 2020) \\
\hline Cao et al. (2012) & Southern Han Chinese & 16 SCAR cases +63 controls & 1 & 0.889 & 0.0186 & 1 & 0.0021 & 476 & 14.0 (Cao et al., 2012) \\
\hline Chung et al. (2015) & Taiwan & 48 cases +138 controls & 0.958 & 0.826 & 0.0115 & 0.9999 & 0.0021 & 497 & 20.0 (Taiwan Han Chinese) (McCabe et al., 2020) \\
\hline Hung et al. (2005) & Taiwan & $\begin{array}{l}51 \text { cases + } 135 \text { tolerant controls + } 93 \\
\text { population controls }\end{array}$ & 1 & 0.852 & 0.0140 & 1 & 0.0021 & 476 & 20.4 (Hung et al., 2005) \\
\hline Ng et al. (2016) & Taiwan & 106 cases +285 controls & 0.906 & 0.821 & 0.0105 & 0.9998 & 0.0021 & 526 & 20.0 (Taiwan Han Chinese) (McCabe et al., 2020) \\
\hline Saksit et al. (2017) & Thailand & 86 cases +182 controls & 0.965 & 0.885 & 0.0173 & 0.9999 & 0.0021 & 493 & 14.8 (Thailand) (McCabe et al., 2020) \\
\hline
\end{tabular}

TABLE 4 | HLA-B5801 and allopurinol induced drug reaction with eosinophilia and systemic symptoms (DRESS).

\begin{tabular}{|c|c|c|c|c|c|c|c|c|c|}
\hline Article & Population & Description & Sensitivity & Specificity & PPV & NPV & Incidence $\mathrm{i}^{\mathrm{i}, \mathrm{iii}}$ & NNG & Frequency carriers in population (\%) \\
\hline Kang et al. (2011) & Korea & 21 DIHS cases + 57 controls & 0.952 & 0.895 & 0.0045 & 1.0000 & 0.0005 & 2100 & 11.8 (South Korea pop 10) (McCabe et al., 2020) \\
\hline Gonçalo et al. (2013) & Portugal & 19 DRESS cases +23 controls & 0.632 & 0.957 & 0.0072 & 0.9998 & 0.0005 & 3167 & 4.0 (Portugal Center) (McCabe et al., 2020) \\
\hline Cao et al. (2012) & Southern Han Chinese & $\begin{array}{l}3 \text { DRESS cases }+63 \text { tolerant controls } \\
+572 \text { population controls }\end{array}$ & 1 & 0.889 & 0.0045 & 1 & 0.0005 & 2000 & 14.0 (Cao et al., 2012) \\
\hline Chung et al. (2015) & Taiwan & 22 DRESS cases + 138 controls & 1 & 0.826 & 0.0029 & 1 & 0.0005 & 2000 & 20.0 (Taiwan Han Chinese) (McCabe et al., 2020) \\
\hline Ng et al. (2016) & Taiwan & 60 DRESS cases +285 controls & 0.917 & 0.821 & 0.0026 & 0.9999 & 0.0005 & 2182 & 20.0 (Taiwan Han Chinese) (McCabe et al., 2020) \\
\hline Sukasem et al. (2016) & Thailand & $\begin{array}{l}6 \text { DRESS cases }+100 \text { tolerant controls } \\
+1095 \text { population controls }\end{array}$ & 1 & 0.960 & 0.0124 & 1 & 0.0005 & 2000 & 10.1 (Sukasem et al., 2016) \\
\hline Saksit et al. (2017) & Thailand & 19 DRESS cases +182 controls & 1 & 0.885 & 0.0043 & 1 & 0.0005 & 2000 & 14.8 (Thailand) (McCabe et al., 2020) \\
\hline
\end{tabular}


TABLE 5 | HLA-B`5801 and allopurinol induced Stevens-Johnson syndrome (SJS)/toxic epidermal necrolysis (TEN).

\begin{tabular}{|c|c|c|c|c|c|c|c|c|c|}
\hline Article & Population & Description & Sensitivity & Specificity & PPV & NPV & Incidence ${ }^{\mathrm{i}, \mathrm{iii}}$ & NNG & $\begin{array}{l}\text { Frequency carriers in } \\
\text { population }(\%)\end{array}$ \\
\hline $\begin{array}{l}\text { Kang et al. } \\
(2011)\end{array}$ & Korea & 5 SJS/TEN cases + 57 controls & 0.800 & 0.895 & 0.0120 & 0.9996 & 0.0016 & 781 & $\begin{array}{l}11.8 \text { (South Korea pop 10) } \\
\text { (McCabe et al., 2020) }\end{array}$ \\
\hline $\begin{array}{l}\text { Gonçalo et al. } \\
\text { (2013) }\end{array}$ & Portugal & 6 SJS/TEN cases +23 controls & 0.667 & 0.957 & 0.0240 & 0.9994 & 0.0016 & 938 & $\begin{array}{l}4.0 \text { (Portugal Center) } \\
\text { (McCabe et al., 2020) }\end{array}$ \\
\hline $\begin{array}{l}\text { Cao et al. } \\
(2012)\end{array}$ & $\begin{array}{l}\text { Southern } \\
\text { Han Chinese }\end{array}$ & $\begin{array}{l}13 \text { SJS/TEN cases + } 63 \text { tolerant } \\
\text { controls }+572 \text { population controls }\end{array}$ & 1 & 0.889 & 0.0142 & 1 & 0.0016 & 625 & 14.0 (Cao et al., 2012) \\
\hline $\begin{array}{l}\text { Chung et al. } \\
\text { (2015) }\end{array}$ & Taiwan & 26 SJS/TEN cases + 138 controls & 0.923 & 0.826 & 0.0084 & 0.9999 & 0.0016 & 677 & $\begin{array}{l}20.0 \text { (Taiwan Han Chinese) } \\
\text { (McCabe et al., 2020) }\end{array}$ \\
\hline Ng et al. (2016) & Taiwan & 46 SJS/TEN cases + 285 controls & 0.891 & 0.821 & 0.0079 & 0.9998 & 0.0016 & 701 & $\begin{array}{l}20.0 \text { (Taiwan Han Chinese) } \\
\text { (McCabe et al., 2020) }\end{array}$ \\
\hline $\begin{array}{l}\text { Sukasem et al. } \\
\text { (2016) }\end{array}$ & Thailand & $\begin{array}{l}13 \text { SJS-TEN cases + } 100 \text { tolerant } \\
\text { controls }+1095 \text { population controls }\end{array}$ & 1 & 0.96 & 0.0385 & 1 & 0.0016 & 625 & 10.1 (Sukasem et al., 2016) \\
\hline $\begin{array}{l}\text { Tassaneeyakul } \\
\text { et al. (2009) }\end{array}$ & Thailand & 27 SJS/TEN cases + 54 controls & 1 & 0.870 & 0.0122 & 1 & 0.0016 & 625 & $\begin{array}{l}14.8 \text { (Thailand) (McCabe } \\
\text { et al., 2020) }\end{array}$ \\
\hline $\begin{array}{l}\text { Saksit et al. } \\
(2017)\end{array}$ & Thailand & 67 SJS/TEN cases + 182 controls & 0.955 & 0.885 & 0.0131 & 0.9999 & 0.0016 & 654 & 14.8 (Thailand) (2020) \\
\hline
\end{tabular}

TABLE 6 | HLA-B*5701 and flucloxacillin induced drug-induced liver injury (DILI).

\begin{tabular}{|c|c|c|c|c|c|c|c|c|}
\hline Article & Population & Description & Sensitivity & Specificity & PPV & NPV & Incidence ${ }^{\mathrm{iii}}$ & NNG \\
\hline
\end{tabular}

However, only four studies for oxcarbazepine and hypersensitivity are identified. Three of these four studies were studying oxcarbazepine induced MPE and only one study investigated oxcarbazepine induced SJS/TEN (He et al., 2012; Lv et al., 2013; Moon et al., 2016; Chen et al., 2017). This may be due to the fact oxcarbazepine-induced SJS/TEN is less common than carbamazepine-induced SJS/TEN. Results of the study can be found in Table 12. The incidence used for calculations is $0.0826 \%$ (Chen et al., 2017; Koninklijke Nederlandse Maatschappij ter bevordering der Pharmacie, 2020e).

Chen et al. investigated the association of HLA-B*1502 and oxcarbazepine induced cutaneous adverse drug reactions including SJS/TEN in Taiwanese and Thai Han Chinese. However, because there were only three Thai cases and no tolerant controls, we do not report this data. Sensitivity for Taiwanese Han Chinese is 70.6\% and specificity is $92.1 \%$. The NNG for Taiwanese Han Chinese 1715.

\section{Lamotrigine}

Lamotrigine is approved for epilepsy and for bipolar disorders. There is evidence HLA-B ${ }^{\star} 1502$ is associated with lamotrigine induced SJS/TEN. The drug label of lamotrigine does give a warning about serious skin rashes including SJS usually occurring within 2-8 weeks of initiation of lamotrigine. The incidence is higher in pediatric patients than adults. Interestingly, HLA-B ${ }^{\star} 1502$ is not mentioned in the drug label at all (GlaxoSmithKline, 2009).

We have identified nine articles about lamotrigine and hypersensitivity that meet our inclusion criteria. Of these only five articles report information about the association of HLA-B ${ }^{\star} 1502$ and lamotrigine induced SJS/TEN, the other studies investigate other endpoints such as DRESS or MPE. The results of the studies investigating SJS/TEN can be found in Table 13.
The incidence of lamotrigine induced SJS/TEN is assumed to be $0.1 \%$ (Koninklijke Nederlandse Maatschappij ter bevordering der Pharmacie, 2020d).

The HLA-B ${ }^{\star} 1502$ test shows low sensitivity $(0 \%-33.3 \%)$ but high specificity $(81.4 \%-100 \%)$ in various populations. the NNG is with 3,000-4,400 much higher than for carbamazepine and oxcarbazepine.

\section{Phenytoin}

Phenytoin is an AED but is in some countries also approved as a class $1 \mathrm{~b}$ antiarrhythmic. There is evidence HLA-B ${ }^{\star} 1502$ is associated with phenytoin induced SJS/TEN as mentioned in the DPWG and CPIC guidelines (Caudle et al., 2014; Koninklijke Nederlandse Maatschappij ter bevordering der Pharmacie, 2020f). Also the drug label mentions this association but states that the evidence is weak. The label mentions consideration should be given to avoid phenytoin as an alternative for carbamazepine in patients positive for HLA-B ${ }^{\star} 1502$ (Pfizer, 2016).

We have identified 10 articles about phenytoin and hypersensitivity that meet our inclusion criteria. Of these 10 articles, eight articles report information about the association of HLA-B ${ }^{\star} 1502$ and phenytoin induced SJS/TEN. The results of these studies can be found in Table 14.

The incidence of phenytoin induced SJS/TEN is assumed to be 0.24\% in Asians and $0.069 \%$ in Caucasians (Fowler et al., 2019; Koninklijke Nederlandse Maatschappij ter bevordering der Pharmacie, 2020f).

The sensitivity of HLA-B ${ }^{\star} 1502$ for phenytoin induced SJS/TEN in the included studies differs from $12.8 \%$ to $100 \%$. Of note, the study of Locharernkul et al. (2008) reporting a sensitivity of 100\% has only four SJS cases. The second highest sensitivity found is only $61.5 \%$. The specificity is $77.5 \%-94.9 \%$ which is quite low compared 


\begin{tabular}{|c|c|c|c|c|c|c|c|c|c|}
\hline Article & Population & Description & Sensitivity & Specificity & PPV & NPV & Incidence & NNG & Frequency carriers in population (\%) \\
\hline Amstutz et al. (2013) & Canada & $\begin{array}{l}42 \text { cases ( } 9 \text { SJS/TEN, } 6 \text { HSS, } 26 \text { MPE, } 1 \\
\text { AGEP) + } 92 \text { controls }\end{array}$ & 0.333 & 0.989 & 0.0014 & 0.99996 & 0.00005 & 60000 & $\begin{array}{l}\text { No data available of Canadians or North Americans of } \\
\text { mixed ethnicity. (McCabe et al., 2020) }\end{array}$ \\
\hline Wu et al. (2010) & Central China & $\begin{array}{l}36 \text { cases }(8 \mathrm{SJS} / \mathrm{TEN}+28 \mathrm{MPE})+50 \\
\text { tolerant controls }+71 \text { population controls }\end{array}$ & 1 & 0.92 & 0.0303 & 1 & 0.0025 & 400 & 8.5 (Wu et al., 2010) \\
\hline He et al. (2013) & $\begin{array}{l}\text { China Northeast } \\
\text { Han Chinese }\end{array}$ & 35 SJS/TEN cases +125 controls & 0.229 & 0.984 & 0.0346 & 0.9980 & 0.0025 & 1750 & 3.8 (China North Han) (McCabe et al., 2020) \\
\hline Shi et al. (2012) & $\begin{array}{l}\text { China Southern } \\
\text { Han Chinese }\end{array}$ & 18 SJS/TEN cases +93 controls & 0.722 & 0.886 & 0.0160 & 0.992 & 0.0025 & 554 & 13.7 (China South Han) (McCabe et al., 2020) \\
\hline Shi et al. (2017) & $\begin{array}{l}\text { China Southern } \\
\text { Han Chinese }\end{array}$ & 56 SJS/TEN cases +180 controls & 0.696 & 0.844 & 0.0110 & 0.9991 & 0.0025 & 574 & 13.7 (China South Han) (McCabe et al., 2020) \\
\hline Cheung et al. (2013) & $\begin{array}{l}\text { Hong Kong Han } \\
\text { Chinese }\end{array}$ & 26 SJS/TEN cases + 135 controls & 0.923 & 0.881 & 0.0191 & 0.9998 & 0.0025 & 433 & 17.9 (Hong Kong Chinese BMDR) (McCabe et al., 2020) \\
\hline Khosama et al. (2017) & Indonesia & 14 SJS/TEN cases + 53 controls & 0.571 & 0.736 & 0.0054 & 0.9985 & 0.0025 & 700 & 22.9 (Indonesia Java Western) (McCabe et al., 2020) \\
\hline Kim et al. (2011) & Korea & $\begin{array}{l}24 \text { SCAR cases ( } 7 \text { SJS, } 17 \text { HSS })+50 \\
\text { tolerant controls + } 485 \text { population controls }\end{array}$ & 0.143 & 1 & 1 & 0.9979 & 0.0025 & 2800 & 0.4 (Kim et al., 2011) \\
\hline \multirow[t]{4}{*}{ Khor et al. (2017) } & Malaysia & 28 SJS/TEN cases + 227 controls & 0.714 & 0.899 & 0.0174 & 0.9992 & 0.0025 & 560 & \\
\hline & Malaysia Chinese & 6 cases +106 controls & 0.667 & 0.877 & 0.0134 & 0.9990 & 0.0025 & 600 & 11.3 (Malaysia Peninsular Chinese) (McCabe et al., 2020) \\
\hline & Malaysia Indian & 6 cases +57 controls & 0.333 & 0.965 & 0.0233 & 0.9983 & 0.0025 & 1200 & 5.2. (Malaysia Peninsular Indian) (McCabe et al., 2020) \\
\hline & $\begin{array}{l}\text { Malaysia } \\
\text { Malaysian }\end{array}$ & 16 cases +64 controls & 0.875 & 0.875 & 0.0172 & 0.9996 & 0.0025 & 457 & 22.3 (Malaysia Peninsular Malay) (McCabe et al., 2020) \\
\hline Wang et al. (2011) & $\begin{array}{l}\text { Southern Han } \\
\text { Chinese }\end{array}$ & $\begin{array}{l}48 \text { cases ( } 9 \mathrm{SJS} / \mathrm{TEN}, 39 \mathrm{MPE})+80 \\
\text { tolerant controls }+62 \text { population controls }\end{array}$ & 1 & 0.863 & 0.0179 & 1 & 0.0025 & 400 & 17.7 (Wang et al., 2011) \\
\hline Chung et al. (2004) & $\begin{array}{l}\text { Taiwan Han } \\
\text { Chinese }\end{array}$ & $\begin{array}{l}44 \text { SJS cases }+101 \text { tolerant controls }+93 \\
\text { population controls }\end{array}$ & 1 & 0.970 & 0.0781 & 1 & 0.0025 & 400 & 8.6 (Chung et al., 2004) \\
\hline Hsiao et al. (2014) & $\begin{array}{l}\text { Taiwan Han } \\
\text { Chinese }\end{array}$ & $\begin{array}{l}194 \text { cases ( } 51 \text { MPE, } 112 \text { SJS/TEN, } 8 \\
\text { other) }+152 \text { controls }\end{array}$ & 0.884 & 0.928 & 0.0297 & 0.9997 & 0.0025 & 453 & 8.8 (Taiwan Han Chinese) (McCabe et al., 2020) \\
\hline $\begin{array}{l}\text { Kulkantrakorn et al. } \\
\text { (2012) }\end{array}$ & Thailand & 34 SJS/TEN cases +40 controls & 0.941 & 0.825 & 0.0133 & 0.9998 & 0.0025 & 425 & 16.1 (Thailand Northeast pop 2) (McCabe et al., 2020) \\
\hline $\begin{array}{l}\text { Locharernkul et al. } \\
\text { (2008) }\end{array}$ & Thailand & 15 cases (6 SJS, 9 MPE) + 42 controls & 1 & 0.810 & 0.0130 & 1 & 0.0025 & 400 & 16.1 (Thailand Northeast pop 2) (McCabe et al., 2020) \\
\hline Sukasem et al. (2018) & Thailand & $\begin{array}{l}38 \text { cases ( } 17 \mathrm{MPE}, 16 \mathrm{SJS} / \mathrm{TEN}, 5 \\
\text { DRESS) }+271 \text { tolerant controls }+470 \\
\text { population controls }\end{array}$ & 0.75 & 0.959 & 0.0443 & 0.993 & 0.0025 & 533 & 15.1 (Sukasem et al., 2018) \\
\hline $\begin{array}{l}\text { Tassaneeyakul et al. } \\
\text { (2010) }\end{array}$ & Thailand & 42 SJS/TEN cases and 42 controls & 0.881 & 0.881 & 0.0182 & 0.9997 & 0.0025 & 454 & 16.1 (Thailand Northeast pop 2) (McCabe et al., 2020) \\
\hline Nguyen et al. (2015) & Vietnam & $\begin{array}{l}38 \text { cases (20 SJS, } 7 \text { TEN, } 8 \text { SJS-TEN, } 3 \\
\text { DRESS) + } 25 \text { controls }\end{array}$ & 0.914 & 0.760 & 0.0095 & 0.997 & 0.0025 & 438 & 25,2 (Vietnam Hanoi Kinh pop 2) (McCabe et al., 2020) \\
\hline Genin et al. (2014) & European & $\begin{array}{l}20 \text { SJS/TEN cases, } 10 \text { DRESS cases }+43 \\
\text { tolerant controls from other study }+8862 \\
\text { population controls }\end{array}$ & 0 & 1 & - & 1 & 0.00005 & - & 0.05 (Genin et al., 2014) \\
\hline Genin et al. (2014) & $\begin{array}{l}\text { Chinese from } \\
\text { Taiwan }\end{array}$ & $\begin{array}{l}53 \text { SJS/TEN cases, } 10 \text { DRESS cases }+72 \\
\text { tolerant controls }+710 \text { population controls }\end{array}$ & 0.774 & 0.44 & 0.033 & 0.994 & 0.0025 & 517 & 8.5 (Genin et al., 2014) \\
\hline
\end{tabular}


TABLE 8 | HLA-B*1511 and carbamazepine induced Stevens-Johnson syndrome (SJS)/toxic epidermal necrolysis (TEN).

\begin{tabular}{|c|c|c|c|c|c|c|c|c|c|}
\hline Article & Population & Description & Sensitivity & Specificity & PPV & NPV & Incidence & NNG & $\begin{array}{c}\text { Frequency carriers in } \\
\text { population (\%) }\end{array}$ \\
\hline $\begin{array}{l}\text { Kim et al. } \\
\text { (2011) }\end{array}$ & Korea & $\begin{array}{l}24 \text { SCAR cases ( } 7 \text { SJS, } 17 \text { HSS })+50 \\
\text { tolerant controls }+485 \text { population } \\
\text { controls }\end{array}$ & 0.429 & 0.96 & 0.0262 & 0.9985 & 0.0025 & 933 & 3.9 (Kim et al., 2011) \\
\hline $\begin{array}{l}\text { Shi et al. } \\
\text { (2012) }\end{array}$ & $\begin{array}{l}\text { China Southern } \\
\text { Han Chinese }\end{array}$ & 56 SJS/TEN cases + 180 controls & 0.071 & 0.843 & 0.0011 & 0.9972 & 0.0025 & 5600 & $\begin{array}{l}0.4 \text { (China South Han) } \\
\text { (McCabe et al., 2020) }\end{array}$ \\
\hline
\end{tabular}

TABLE 9 | HLA-A*3101 and carbamazine induced Stevens-Johnson syndrome (SJS)/toxic epidermal necrolysis (TEN).

\begin{tabular}{|c|c|c|c|c|c|c|c|c|c|}
\hline Article & Population & Description & Sensitivity & Specificity & PPV & NPV & Incidence & NNG & $\begin{array}{l}\text { Frequency carriers } \\
\text { in population }(\%)\end{array}$ \\
\hline $\begin{array}{l}\text { Amstutz et al. } \\
\text { (2013) }\end{array}$ & Canada & $\begin{array}{l}42 \text { cases ( } 9 \text { SJS/TEN, } 6 \text { HSS, } \\
26 \text { MPE, } 1 \text { AGEP) + } 92 \\
\text { controls }\end{array}$ & 0 & 0.967 & 0 & 0.9999 & 0.00005 & - & $\begin{array}{l}\text { No data available of } \\
\text { Canadians or North } \\
\text { Americans of mixed } \\
\text { ethnicity. }\end{array}$ \\
\hline $\begin{array}{l}\text { Hsiao et al. } \\
\text { (2014) }\end{array}$ & $\begin{array}{l}\text { Han Chinese from } \\
\text { Taiwan }\end{array}$ & $\begin{array}{l}194 \text { cases (51 MPE, } 112 \\
\text { SJS/TEN, } 8 \text { other) + } 152 \\
\text { controls (investigates } \\
\text { associations) }\end{array}$ & 0.018 & 0.967 & 0.0014 & 0.9974 & 0.0025 & 22400 & $\begin{array}{l}5.5 \text { (Taiwan Han Chinese) } \\
\text { (McCabe et al., 2020) }\end{array}$ \\
\hline $\begin{array}{l}\text { Ozeki et al. } \\
\text { (2011) }\end{array}$ & Japan & $\begin{array}{l}77 \text { cADR cases ( } 36 \text { DIHS, } 6 \\
\text { SJS/TEN, } 35 \text { other) }+420 \\
\text { controls }\end{array}$ & 0.833 & 0.871 & 0.0160 & 0.9995 & 0.0025 & 480 & $\begin{array}{l}16.1 \text { (Japan pop 16) } \\
\text { (McCabe et al., 2020) }\end{array}$ \\
\hline $\begin{array}{l}\text { Kim et al. } \\
(2011)\end{array}$ & Korea & $\begin{array}{l}24 \text { SCAR cases ( } 7 \text { SJS, } 17 \\
\text { HSS) }+50 \text { tolerant controls + } \\
485 \text { population controls }\end{array}$ & 0.429 & 0.86 & 0.0076 & 0.9983 & 0.0025 & 933 & 10.3 (Kim et al., 2011) \\
\hline \multirow[t]{4}{*}{$\begin{array}{l}\text { Khor et al. } \\
\text { (2017) }\end{array}$} & Malaysia & $\begin{array}{l}28 \text { SJS/TEN cases }+227 \\
\text { controls }\end{array}$ & 0.107 & 0.947 & 0.0051 & 0.9976 & 0.0025 & 3733 & \\
\hline & Malaysia Chinese & 6 cases +106 controls & 0 & 0.972 & 0 & 0.9974 & 0.0025 & - & $\begin{array}{l}2.6 \text { (Malaysia Peninsular } \\
\text { Chinese) (McCabe et al., } \\
\text { 2020) }\end{array}$ \\
\hline & Malaysia Indian & 6 cases +57 controls & 0.500 & 0.912 & 0.0141 & 0.9986 & 0.0025 & 800 & $\begin{array}{l}\text { 4.1 (Malaysia Peninsular } \\
\text { Indian) (McCabe et al., } \\
\text { 2020) }\end{array}$ \\
\hline & Malaysia Malaysian & 16 cases +64 controls & 0 & 0.938 & 0 & 0.9973 & 0.0025 & - & $\begin{array}{l}0.8 \text { (Malaysia Peninsular } \\
\text { Malay) (McCabe et al., 2020) }\end{array}$ \\
\hline $\begin{array}{l}\text { Ihtisham et al. } \\
\text { (2019) }\end{array}$ & North India & $\begin{array}{l}35 \text { cases ( } 27 \text { MPE/ } 6 \text { SJS- } \\
\text { TEN/2 DRESS) }+70 \text { controls }\end{array}$ & 0 & 0.957 & 0 & 0.9974 & 0.0025 & - & $\begin{array}{l}3.8 \text { (India North pop 2) } \\
\text { (McCabe et al., 2020) }\end{array}$ \\
\hline $\begin{array}{l}\text { Genin et al. } \\
\text { (2014) }\end{array}$ & European & $\begin{array}{l}20 \text { SJS/TEN cases, } 10 \\
\text { DRESS cases }+257 \text { tolerant } \\
\text { controls }+8862 \text { population } \\
\text { controls }\end{array}$ & 0.150 & 0.961 & 0.0002 & 0.99996 & 0.00005 & 133333 & 4.5 (Genin et al., 2014) \\
\hline $\begin{array}{l}\text { Genin et al. } \\
\text { (2014) }\end{array}$ & $\begin{array}{l}\text { Chinese from } \\
\text { Taiwan }\end{array}$ & $\begin{array}{l}53 \text { SJS/TEN cases, } 10 \\
\text { DRESS cases }+72 \text { tolerant } \\
\text { controls }+710 \text { population } \\
\text { controls }\end{array}$ & 0.019 & 0.958 & 0.0011 & 0,9974 & 0.0025 & 21200 & 3.7 (Genin et al., 2014) \\
\hline
\end{tabular}

to the other drug-gene interactions in this review. The PPV is low $(0.2 \%-1.4 \%)$ meaning false positives are common. The NNG to prevent one case of phenytoin induced SJS/TEN is $417-3,250$.

\section{DISCUSSION}

In this review we provide a systematic overview of the diagnostic test criteria for HLA- genotyping to prevent drug hypersensitivity reactions. We have focused on the seven drugs for which actionable CPIC and/or DPWG guidelines are available. In general, specificity of all included HLA tests for drug hypersensitivity is high (80\%-100\%). Sensitivity shows a larger variability ranging from $100 \%$ for HLA-B ${ }^{\star} 5701$ testing and immunologically confirmed ABC-HSR to less than $30 \%$ for HLA-B ${ }^{\star} 5701$ testing and lamotrigine induced SJS/TEN. For allopurinol induced SCAR and HLA-B ${ }^{\star} 5801$ and flucloxacillin induced DILI and HLA-B ${ }^{\star} 5701$ sensitivity is high. For the other drugs and associated HLA variants, a wide range of sensitivities are found. Due to the rarity of some of the included hypersensitivity reactions, the NNG is very high for some drugs, especially for flucloxacillin and lamotrigine. Taking into consideration the low NNG of around 40 in combination with the severity of the side effect, it may not be surprising that HLA-B ${ }^{\star} 1502$ testing is mandatory for abacavir. Pre-emptively testing HLA-B ${ }^{\star} 1502$ for Asian carbamazepine initiators and HLA-B ${ }^{\star} 5801$ for high-risk allopurinol initiators could also be worthwhile. 
TABLE 10 | HLA-B`3101 and carbamazepine induced drug reaction with eosinophilia and systemic symptoms (DRESS).

\begin{tabular}{|c|c|c|c|c|c|c|c|c|c|}
\hline Article & Population & Description & Sensitivity & Specificity & PPV & NPV & Incidence & NNG & Frequency carriers in population (\%) \\
\hline Amstutz et al. (2013) & Canada & 42 cases ( 9 SJS/TEN, 6 HSS, 26 MPE, 1 AGEP) + 92 controls & 0.5 & 0.967 & 0.0075 & 0.9997 & 0.0005 & 4000 & $\begin{array}{l}\text { No data available of Canadians or North } \\
\text { Americans of mixed ethnicity. }\end{array}$ \\
\hline Genin et al. (2014) & $\begin{array}{l}\text { Chinese from } \\
\text { Taiwan }\end{array}$ & $\begin{array}{l}53 \text { SJS/TEN cases, } 10 \text { DRESS cases }+72 \text { tolerant controls + } \\
710 \text { population controls }\end{array}$ & 0.5 & 0.958 & 0.0060 & 0.9997 & 0.0005 & 4000 & 3.7 (Genin et al., 2014) \\
\hline Genin et al. (2014) & European & $\begin{array}{l}20 \text { SJS/TEN cases, } 10 \text { DRESS cases }+257 \text { tolerant controls } \\
\text { from other study }+8,862 \text { population controls }\end{array}$ & 0.7 & 0.961 & 0,0089 & 0.9998 & 0.0005 & 2857 & 4.5 (Genin et al., 2014) \\
\hline Hsiao et al. (2014) & $\begin{array}{l}\text { Han Chinese } \\
\text { from Taiwan }\end{array}$ & 194 cases (51 MPE, 112 SJS/TEN, 8 other) + 152 controls & 0.304 & 0.967 & 0.0046 & 0.9996 & 0.0005 & 6571 & $\begin{array}{l}5.5 \text { (Taiwan Han Chinese) (McCabe et al., } \\
\text { 2020) }\end{array}$ \\
\hline Ozeki et al. (2011) & Japan & 77 cADR cases (36 DIHS, 6 SJS/TEN, 35 other) + 420 controls & 0.583 & 0.871 & 0.0023 & 0.9998 & 0.0005 & 3429 & $\begin{array}{l}16.1 \text { (Japan pop 16) (McCabe et al., } \\
\text { 2020) }\end{array}$ \\
\hline Kim et al. (2011) & Korea & $\begin{array}{l}24 \text { SCAR cases ( } 7 \text { SJS, } 17 \text { HSS })+50 \text { tolerant controls + } 485 \\
\text { population controls }\end{array}$ & 0.588 & 0.86 & 0.0021 & 0.0098 & 0.0005 & 3400 & 10.3 (Kim et al., 2011) \\
\hline Itisham et al. (2019) & North India & 35 cases (27 MPE/6 SJS-TEN/2 DRESS) +70 controls & 0 & 0.957 & 0 & 0.9995 & 0.0005 & - & $\begin{array}{l}3.8 \text { (India North pop 2) (McCabe et al., } \\
\text { 2020) }\end{array}$ \\
\hline
\end{tabular}

TABLE 11 | HLA-B`3101 and carbamazepine induced maculopapular exanthema (MPE).

\begin{tabular}{|c|c|c|c|c|c|c|c|c|c|}
\hline Article & Population & Description & Sensitivity & Specificity & PPV & NPV & Incidence & NNG & Frequency carriers in population (\%) \\
\hline Amstutz et al. (2013) & $\begin{array}{l}\text { Canada with diverse } \\
\text { ethnic background }\end{array}$ & $\begin{array}{l}42 \text { cases ( } 9 \text { SJS/TEN, } 6 \text { HSS, } 26 \text { MPE, } 1 \text { AGEP) + } 92 \\
\text { controls }\end{array}$ & 0.231 & 0.967 & 0.438 & 0.919 & 0.1 & 43 & $\begin{array}{l}\text { No data available of Canadians or North } \\
\text { Americans of mixed ethnicity. }\end{array}$ \\
\hline Li et al. (2013) & China Han Chinese & $\begin{array}{l}40 \text { MPE cases }+52 \text { controls }+72 \text { population controls } \\
\text { (allele frequency instead of carrier frequency) }\end{array}$ & 0.013 & 0.990 & 0.056 & 0.956 & 0.044 & 1818 & $\begin{array}{l}3.0 \text { (China Sichuan HIV negative (McCabe } \\
\text { et al., 2020) }\end{array}$ \\
\hline $\begin{array}{l}\text { McCormack et al. } \\
\text { (2018) }\end{array}$ & European descended & 95 MPE cases + 869 controls & 0.168 & 0.969 & 0.376 & 0.913 & 0.1 & 59 & 4.6 (Poland BMR) (McCabe et al., 2020) \\
\hline McCormack et al. & $\begin{array}{l}\text { Han Chinese } \\
\text { descended }\end{array}$ & 85 MPE cases + 197 controls & 0.043 & 0.940 & 0.032 & 0.955 & 0.044 & 523 & $\begin{array}{l}12.2 \text { (China Han HIV negative) (McCabe } \\
\text { et al., 2020) }\end{array}$ \\
\hline Hsiao et al. (2014) & $\begin{array}{l}\text { Han Chinese from } \\
\text { Taiwan }\end{array}$ & $\begin{array}{l}194 \text { cases ( } 51 \text { MPE, } 112 \text { SJS/TEN, } 8 \text { other) + } 152 \text { controls } \\
\text { (investigates associations) }\end{array}$ & 0.137 & 0.967 & 0.161 & 0.961 & 0.044 & 166 & $\begin{array}{l}5.5 \text { (Taiwan Han Chinese) (McCabe et al., } \\
\text { 2020) }\end{array}$ \\
\hline Itisham et al. (2019) & North India & 35 cases (27 MPE/6 SJS-TEN/2 DRESS) +70 controls & 0.222 & 0.957 & 0.193 & 0.964 & 0.044 & 102 & $\begin{array}{l}3.8 \text { (India North pop 2) (McCabe et al., } \\
2020)\end{array}$ \\
\hline
\end{tabular}


TABLE 12 | HLA-B`1502 and oxcarbazepine induced Stevens-Johnson syndrome (SJS)/toxic epidermal necrolysis (TEN).

\begin{tabular}{|c|c|c|c|c|c|c|c|c|c|}
\hline Article & Population & Description & Sensitivity & Specificity & PPV & NPV & Incidence $e^{\mathrm{i}, \mathrm{iii}}$ & NNG & $\begin{array}{c}\text { Frequency carriers in } \\
\text { population }(\%)\end{array}$ \\
\hline Chen et al. (2017) & Taiwan Han Chinese & $\begin{array}{l}50 \text { cADR cases ( } 20 \text { SJS- } \\
\text { TEN, } 6 \text { DRESS, } 22 \text { MPE, } 2 \\
\text { BDFE) + } 101 \text { controls }\end{array}$ & 0.706 & 0.921 & 0.0073 & 0.9997 & 0.000826 & 1715 & $\begin{array}{l}8.8 \text { (Taiwan Han Chinese) } \\
\text { (McCabe et al., 2020) }\end{array}$ \\
\hline
\end{tabular}

To our knowledge, this is the first overview of the diagnostic test criteria of drug-HLA interactions for the actionable CPIC and/or DPWG guidelines. A review by Mullan et al. (2019) provides diagnostic test criteria but is limited to four AEDs. A strength of our study is that we calculated the diagnostic test criteria using the original data of genotyping results in cases and controls instead of only reporting diagnostic criteria if they were reported in the original studies. Also, some of the original studies did not take into account the incidence of the endpoint in the general population for calculating the NPV and PPV when this correction should be performed in case of a case-control design (Steinberg et al., 2009; Tonk et al., 2017).

A limitation of the available data is that most of the included studies have a limited sample size with mostly positive results, indicating a high likelihood of publication bias. Therefore presented results may be inflated and true effects may be lower than reported in this review. We included original studies which did not find a significant association of the variant but appeared significant in meta-analyses. This was particularly the case for lamotrigine where none of the selected original studies show a significant association of HLA-B ${ }^{\star} 1502$ and lamotrigine-induced SJS/TEN. However, in two meta-analyses, a significant association has been shown (Zeng et al., 2015; Deng et al., 2018). It must be noted however that also in these meta-analyses, the total number of patients was still low. The first meta-analysis had only 12 cases and 128 controls where the other meta-analysis had 54 cases and 313 controls. Besides the sample size of the studies, the number of studies found may also be a limitation. For flucloxacillin and oxcarbazepine results from only one study are available. Nevertheless, CPIC and/or DWPG released actionable guidelines for these gene-drug interactions and therefore the studies are included in this review. To better estimate the sensitivity, specificity, NPV, PPV and NNG, more and larger studies are warranted.

It should be noted that in the studies investigating HLA genedrug interactions the studied endpoint is often a clinically diagnosed endpoint and the criteria of these endpoints may differ between studies. For example, the symptoms of ABC-HSR are nonspecific and may be difficult to objectify. In a study by Martin et al. (2004) data of some of the patients of the study by Mallal et al. (2002) are re-analyzed with stricter criteria for abacavir hypersensitivity. As a result Martin et al. reports a higher sensitivity of $94.7 \%$ instead of $77.8 \%$ in the original study. Also the difference of sensitivity between clinically diagnosed and immunologically diagnosed abacavir hypersensitivity further confirms the challenges related to the use of a clinical diagnosis as endpoint. Obviously, this has major influence on the estimated parameters such as sensitivity and specificity. When ABC-HSR is immunologically confirmed the sensitivity is $100 \%$, however when clinically diagnosed, the sensitivity is much lower: $31 \%-90 \%$. Also with conditions such as DRESS and SJS/TEN, the clinically diagnosed endpoint may differ between studies resulting in both over- or underestimation. The fact that clinically diagnosing hypersensitivity reactions is difficult is also exemplified by lamotrigine induced SJS. The drug label of lamotrigine states when 14 cases of serious rash associated with hospitalization were reviewed by three expert dermatologists, one dermatologist considered 7 of the 14 cases as SJS, while another dermatologist considered none of the cases to be SJS (GlaxoSmithKline, 2009). In many studies, SCAR is considered to be one endpoint even though it is a composite endpoint combining DRESS and SJS/TEN which are potentially related to two different biomarkers. Because of this, incidence rates of the separate conditions were sometimes hard to find. In this review we report numbers for allopurinol induced-SCAR but we also looked at DRESS and SJS/TEN separately. Sensitivity is high for both SJS/ TEN and DRESS suggesting HLA-B ${ }^{\star} 5801$ is an appropriate biomarker for both endpoints.

For our analysis to calculate NPV, PPV and NNG for casecontrol studies, data on the incidence of the hypersensitivity reaction is needed. The incidence of drug hypersensitivity differs greatly between populations which can be explained by the differences in allele carrier frequencies. For example, the carrier frequency of HLA$\mathrm{B}^{\star} 5801$ in the Portuguese population is approximately $4 \%$ while this is lower in most other European populations. In an Irish population and a German population for instance the carrier frequency of HLA$\mathrm{B}^{\star} 5801$ is only $1 \%$. Also in a Spanish population, geographically close to Portugal, the carrier frequency is already lower with $2.2 \%$. This exemplifies that diagnostic test criteria should not be extrapolated. Since incidences of ADRs in specific populations are sometimes unknown, the best we could do is to assume these incidence figures from the general population. This assumption may influence the calculated NPV, PPV and NNG with the highest potential impact on the latter. The effect on the NPV and PPV will probably be low since NPV is already close to 1 and PPV close to 0 . In these cases, we have made a best estimate based on results of incidence rates in similar populations. We used a systematic three-step approach. First, if available, we used the incidence mentioned in the original article. Next, we would take the incidence from the DPWG or CPIC guideline. Lastly, if no incidence or only a wide range was described in the guidelines, we used the incidence from a similar population derived from an original article. Therefore, we believe our study uses the most accurate incidence figures available for calculating NPV, PPV, and NNG.

Theoretically, in case of rare ADRs such as investigated here, population controls could be an alternative for the methodologically preferred tolerant controls. However, our search revealed the availability of tolerant controls for most gene-drug pairs and therefore we consistently chose using tolerant controls as to avoid confounding since mostly it is unknown if the ADR is also associated with disease susceptibility. 
TABLE 13 | HLA-B¹502 and lamotrigine induced Stevens-Johnson syndrome (SJS)/toxic epidermal necrolysis (TEN).

\begin{tabular}{|c|c|c|c|c|c|c|c|c|c|}
\hline Article & Population & Description & Sensitivity & Specificity & PPV & NPV & Incidence ${ }^{i}$ & NNG & Frequency carriers in population (\%) \\
\hline Kazeem et al. (2009) & European & 22 cases (10 SJS, 12 HSR) + 43 controls & 0 & 1 & - & 0.9990 & 0.001 & - & $\begin{array}{l}0.0 \text { (Bulgaria, Croatia, Czech Republic, Germany, } \\
\text { Ireland Northern, Netherlands, Poland DKMS) } \\
\text { (McCabe et al., 2020) }\end{array}$ \\
\hline An et al. (2010) & Han Chinese & $\begin{array}{l}25 \text { cases ( } 3 \mathrm{SJS} / \mathrm{TEN}, 22 \mathrm{MPE})+21 \text { tolerant } \\
\text { controls }+71 \text { population controls }\end{array}$ & 0.333 & 0.952 & 0.0070 & 0.9993 & 0.001 & 3000 & 8.5 (Koomdee et al., 2017) \\
\hline Shi et al. (2011) & Han Chinese & $\begin{array}{l}14 \text { cADR cases ( } 2 \text { SJS/TEN }+12 \mathrm{MPE})+28 \text { tolerant } \\
\text { controls }+264 \text { population controls }\end{array}$ & 0 & 0.931 & 0 & 0.9989 & 0.001 & - & 14.1 (Shi et al., 2011) \\
\hline Shi et al. (2017) & $\begin{array}{l}\text { Southern Han } \\
\text { Chinese }\end{array}$ & 22 SJS cases + 102 controls & 0.227 & 0.814 & 0.0012 & 0.9991 & 0.001 & 4400 & 13.7 (China South Han) (McCabe et al., 2020) \\
\hline Koomdee et al. (2017) & Thailand & $\begin{array}{l}15 \text { cADR cases ( } 4 \text { SJS, } 1 \text { dress, } 10 \mathrm{MPE})+50 \\
\text { tolerant controls }+986 \text { population controls }\end{array}$ & 0.25 & 0.88 & 0.0021 & 0.9991 & 0.001 & 4000 & 15.5 (Koomdee et al., 2017) \\
\hline
\end{tabular}

TABLE 14 | HLA-B*1502 and phenytoin induced Stevens-Johnson syndrome (SJS)/toxic epidermal necrolysis (TEN).

\begin{tabular}{|c|c|c|c|c|c|c|c|c|c|}
\hline Article & Population & Description & Sensitivity & Specificity & PPV & NPV & Incidence & NNG & Frequency carriers in population (\%) \\
\hline Chang et al. (2017) & Malaysia & $\begin{array}{l}16 \text { SCAR cases ( } 13 \text { SJS/TEN, } 3 \text { DRESS) + } 32 \\
\text { tolerant controls + } 300 \text { population controls }\end{array}$ & 0.615 & 0.781 & 0.0067 & 0.9988 & 0.0024 & 677 & 15.7 (Chang et al., 2017) \\
\hline Cheung et al. (2013) & Hong Kong Han Chinese & 15 SJS/TEN cases +75 controls & 0.467 & 0.8 & 0.0056 & 0.9984 & 0.0024 & 893 & $\begin{array}{l}17.9 \text { (Hong Kong Chinese BMDR) } \\
\text { (McCabe et al., 2020) }\end{array}$ \\
\hline Hung et al. (2010) & Taiwan Han Chinese & $\begin{array}{l}26 \text { SJS/TEN cases }+113 \text { tolerant controls + } \\
93 \text { population controls }\end{array}$ & 0.308 & 0.920 & 0.0092 & 0.9982 & 0.0024 & 1354 & 7.5 (Hung et al., 2010) \\
\hline Locharernkul et al. (2008) & Thailand & $\begin{array}{l}16 \text { SJS or MPE cases ( } 4 \text { SJS, } 12 \text { MPE) + } 45 \\
\text { controls }\end{array}$ & 1 & 0.822 & 0.0134 & 1 & 0.0024 & 417 & $\begin{array}{l}16.1 \text { (Thailand Northeast pop 2) } \\
\text { (McCabe et al., 2020) }\end{array}$ \\
\hline Shi et al. (2017) & $\begin{array}{l}\text { China, Southern Han } \\
\text { Chinese }\end{array}$ & $13 \mathrm{SJS} / \mathrm{TEN}$ cases +40 controls & 0.462 & 0.775 & 0.0049 & 0.9983 & 0.0024 & 903 & $\begin{array}{l}13.7 \text { (China South Han) (McCabe et al., } \\
\text { 2020) }\end{array}$ \\
\hline Su et al. (2019) & Taiwan & $\begin{array}{l}128 \text { SCAR (65 SJS/TEN, } 63 \text { DRESS) cases + } \\
107 \text { MPE cases + } 376 \text { controls }\end{array}$ & 0.308 & 0.949 & 0.0144 & 0.9982 & 0.0024 & 1354 & 10.1 (Taiwan pop 2) (McCabe et al., 2020) \\
\hline $\begin{array}{l}\text { Tassaneeyakul et al. } \\
\text { (2016) }\end{array}$ & Thailand & $\begin{array}{l}60 \text { cases (39 SJS/TEN + } 21 \text { DRESS)+ } 92 \\
\text { controls }\end{array}$ & 0.128 & 0.859 & 0.0022 & 0.9976 & 0.0024 & 3250 & $\begin{array}{l}16.1 \text { (Thailand Northeast pop 2) } \\
\text { (McCabe et al., 2020) }\end{array}$ \\
\hline Yampayon et al. (2017) & Thailand & $\begin{array}{l}36 \text { cases }(15 \text { SJS }+21 \text { DRESS) }+100 \text { tolerant } \\
\text { controls }+758 \text { population controls }\end{array}$ & 0.333 & 0.820 & 0.0044 & 0.9980 & 0.0024 & 1250 & 14.2 \\
\hline
\end{tabular}


For a predictive HLA test to be implemented for pre-emptive testing, the NNG should be low, the clinical endpoint to be prevented should be of high severity and/or mortality and alternative treatments are available. The posterchild example of HLA testing is pre-emptive HLA-B ${ }^{\star} 5701$ testing for abacavir. The HLA-B ${ }^{\star} 5701$ test has a low NNG ( 40). Besides, due to the high incidence of ABC-HSR, the test has a relatively high PPV of about $50 \%$. Therefore when testing positive, there is a $50 \%$ chance the patient will develop abacavir hypersensitivity. The first symptoms of ABC-HSR are relatively mild composing of rash, fever, gastrointestinal disturbances and non-specific complaints as malaise, dizziness and headache. However, re-exposure is potentially fatal. Among patients who received abacavir in clinical trials, the mortality rate was 0.03 percent while the mortality among patients experiencing hypersensitivity symptoms after a rechallenge was around 5\% (Hetherington et al., 2001). Also the mandatory testing as mentioned in the abacavir drug label has greatly stimulated HLA-B ${ }^{\star} 5701$ testing.

By pre-emptively testing patients who are at increased risk of developing hypersensitivity, a lower NNG can be reached. Therefore, based on our results we recommend to consider preemptively testing HLA-B ${ }^{\star} 5801$ in high risk allopurinol initiators and HLA-B ${ }^{\star} 1502$ in Asian carbamazepine initiators. The NNG for HLA-B ${ }^{\star} 5801$ and allopurinol induced SCAR is relatively low, approximately 500 . However, due to the rarity of SCAR, the PPV is low. Therefore, allopurinol should only be withheld after a positive test result when alternative drugs for treatment are available. The NNG can be reduced 5-10 folds when testing only high risk patients such as patients with chronic renal insufficiency. Two studies find an incidence of allopurinol induced SCAR of $1 \%-$ $2 \%$ in patients with chronic renal insufficiency, which is $5-10$ times higher than the incidence in the overall allopurinol initiators (Jung et al., 2011; Park et al., 2019). By pre-emptively testing only patients with chronic renal insufficiency who are at higher risk of developing SCAR, the NNG would decrease to 50-100 patients.

For Asian carbamazepine initiators we consider the NNG of 500 to be low enough for pre-emptively testing. In this situation, the availability of alternative drugs for treatment is of major importance. When a patient is $\mathrm{HLA}^{*}{ }^{\star} 1502$ positive, the CPIC and/or DPWG recommendations advise to avoid the use of carbamazepine and to also avoid lamotrigine, phenytoin and oxcarbazepine when possible. Due to the rarity of the outcome, the positive predictive value is lower than $1 \%$ for HLA-B ${ }^{\star} 1502$ and SJS/TEN so false positives are common. This means for every 100 patients who switch to another AED, only one case of SJS/TEN is prevented while the alternative therapy may be suboptimal for the particular patient. The NNG can be lower than 500 when testing only in patients who are at higher risk such as patients with an Human immunodeficiency virus (HIV) infection. Patients with HIV infection have been reported to have a 100 -fold higher risk of SJS/TEN than the general population. Also patients with active malignancy have an increased risk of SJS/TEN (High, 2020).

The aim of our review is to give an overview of diagnostic test criteria and this may help clinicians to decide which HLA tests could be implemented. The DPWG introduced the clinical implication score to assist this decision (Swen et al., 2018). The clinical implication score takes into account the clinical effect of the drug-gene interaction, the level of evidence, the NNG and pharmacogenetics information included in the drug label. Druggene pairs can be scored as essential, beneficial and potentially beneficial. When scored as essential, the DPWG concludes genotyping must be performed before initiation of drug therapy. For beneficial drug-gene interactions the DPWG recommends genotyping the patients before or directly after initiation of drug therapy. When scored as potentially beneficial, the DPWG states genotyping should be considered on an individual patient basis, but when genetic information is available, they recommend adhering to the guideline. The DPWG considers HLA-B ${ }^{\star} 5701$ testing essential for abacavir. HLA-B ${ }^{\star} 1502$ testing for oxcarbazepine and lamotrigine were scored to be beneficial. Other HLA-drug interactions have not yet been given a clinical implication score.

In this review we provide a systematic overview of the diagnostic test criteria for actionable drug-HLA gene interactions. In general, specificity and NPV of the HLA tests to predict drug hypersensitivity reactions are high whereas sensitivity shows a wide range across the different tests, ranging from $0-33 \%$ for HLA-B ${ }^{\star} 1502$ testing to predict lamotrigine induced SJS/TEN up to $100 \%$ for HLA-B ${ }^{\star} 5701$ to predict immunologically confirmed ABC-HSR. PPV is low for all tests where HLA-B ${ }^{\star} 5701$ testing for abacavir has the highest PPV of approximately $50 \%$. The NNG is low for HLA-B testing for flucloxacillin and lamotrigine. HLA$B^{\star 5701 ~ t e s t i n g ~ t o ~ p r e d i c t ~ A B C-H S R ~ s h o w s ~ t h e ~ l o w e s t ~ N N G ~}$ followed by HLA-B ${ }^{\star} 5801$ for allopurinol induced SCAR and HLA-B $^{\star} 1502$ for carbamazepine induced SJS/TEN.

\section{AUTHOR CONTRIBUTIONS}

LM performed the literature review and systemic analysis and contributed to writing the manuscript. JS and H-JG contributed to writing the manuscript. All authors contributed to the article and approved the submitted version.

\section{FUNDING}

The research leading to these results has received funding from the European Community's Horizon 2020 Programme under grant agreement No. 668353 (U-PGx).

\section{ACKNOWLEDGMENTS}

We are grateful for the assistance for the search terms given by Jan Schoones of the Walaeus library (LUMC).

\section{SUPPLEMENTARY MATERIAL}

The Supplementary Material for this article can be found online at: https://www.frontiersin.org/articles/10.3389/fphar.2020.567048/ full\#supplementary-material 


\section{REFERENCES}

Agbaji, O. O., Akanbi, M. O., Otoh, I., Agaba, P. E., Akinsola, R., Okolie, V., et al. (2019). Absence of human leukocyte antigen-B ${ }^{\star 57: 01}$ amongst patients on antiretroviral therapy in Nigeria: Implications for use of abacavir. Nigerian Postgrad. Med. J. 26 (4), 195-198. doi: 10.4103/npmj.npmj_75_19

Alvestad, S., Lydersen, S., and Brodtkorb, E. (2008). Cross-reactivity pattern of rash from current aromatic antiepileptic drugs. Epilepsy Res. 80 (2-3), 194-200. doi: 10.1016/j.eplepsyres.2008.04.003

Amstutz, U., Ross, C. J., Castro-Pastrana, L. I., Rieder, M. J., Shear, N. H., Hayden, M. R., et al. (2013). HLA-A 31:01 and HLA-B 15:02 as genetic markers for carbamazepine hypersensitivity in children. Clin. Pharmacol. Ther. 94 (1), 142149. doi: 10.1038/clpt.2013.55

An, D. M., Wu, X. T., Hu, F. Y., Yan, B., Stefan, H., and Zhou, D. (2010). Association study of lamotrigine-induced cutaneous adverse reactions and HLA-B ${ }^{\star} 1502$ in a Han Chinese population. Epilepsy Res. 92 (2-3), 226-230. doi: 10.1016/j.eplepsyres.2010.10.006

Aurobindo Pharma, B. V. (2019). Floxapen, poeder voor orale suspensie $125 \mathrm{mg} / 5$ $m l$. (Baarn, Netherlands).

Berka, N., Gill, J. M., Liacini, A., O’Bryan, T., and Khan, F. M. (2012). Human leukocyte antigen (HLA) and pharmacogenetics: screening for HLA-B*57:01 among human immunodeficiency virus-positive patients from southern Alberta. Hum. Immunol. 73 (2), 164-167. doi: 10.1016/j.humimm.2011.12.002

Bloch, K. M., Sills, G. J., Pirmohamed, M., and Alfirevic, A. (2014). Pharmacogenetics of antiepileptic drug-induced hypersensitivity. Pharmacogenomics 15 (6), 857-868. doi: 10.2217/pgs.14.65

Brothers C, W. P., Sutherland-Phillips, D., and Hernandez, J. (2006) Lower reported rate of suspected hypersensitivity reaction (HSR) to abacavir (ABC) among black patients [abstract H-1065]. In Program and abstracts of the 46th Interscience Conference on Antimicrobial Agents and Chemotherapy. (San Francisco).

Cacoub, P., Musette, P., Descamps, V., Meyer, O., Speirs, C., Finzi, L., et al. (2011). The DRESS syndrome: a literature review. Am. J. Med. 124 (7), 588-597. doi: 10.1016/j.amjmed.2011.01.017

Cao, Z. H., Wei, Z. Y., Zhu, Q. Y., Zhang, J. Y., Yang, L., Qin, S. Y., et al. (2012). HLA-B $^{\star} 58: 01$ allele is associated with augmented risk for both mild and severe cutaneous adverse reactions induced by allopurinol in Han Chinese. Pharmacogenomics 13 (10), 1193-1201. doi: 10.2217/pgs.12.89

Caudle, K. E., Rettie, A. E., Whirl-Carrillo, M., Smith, L. H., Mintzer, S., Lee, M. T., et al. (2014). Clinical pharmacogenetics implementation consortium guidelines for CYP2C9 and HLA-B genotypes and phenytoin dosing. Clin. Pharmacol. Ther. 96 (5), 542-548. doi: 10.1038/clpt.2014.159

Chang, C. C., Ng, C. C., Too, C. L., Choon, S. E., Lee, C. K., Chung, W. H., et al. (2017). Association of HLA-B ${ }^{\star} 15: 13$ and HLA-B ${ }^{\star} 15: 02$ with phenytoininduced severe cutaneous adverse reactions in a Malay population. Pharmacogenom. J. 17 (2), 170-173. doi: 10.1038/tpj.2016.10

Chen, Y. C., Chiu, H. C., and Chu, C. Y. (2010). Drug reaction with eosinophilia and systemic symptoms: a retrospective study of 60 cases. Arch. Dermatol. 146 (12), 1373-1379. doi: 10.1001/archdermatol.2010.198

Chen, Z., Zhang, S., Zhang, J., Zhang, Y., Xue, L., and Miao, L. (2015). Rs9263726 is a specific genetic marker for allopurinol-induced severe cutaneous adverse reactions in Chinese patients. Personalized Med. 12 (6), 585-592. doi: 10.2217/ pme. 15.38

Chen, C. B., Hsiao, Y. H., Wu, T., Hsih, M. S., Tassaneeyakul, W., Jorns, T. P., et al. (2017). Risk and association of HLA with oxcarbazepine-induced cutaneous adverse reactions in Asians. Neurology 88 (1), 78-86. doi: 10.1212/ WNL.0000000000003453

Cheng, L., Xiong, Y., Qin, C. Z., Zhang, W., Chen, X. P., Li, J., et al. (2015). HLA$\mathrm{B}^{\star 58: 01}$ is strongly associated with allopurinol-induced severe cutaneous adverse reactions in Han Chinese patients: a multicentre retrospective casecontrol clinical study. Br. J. Dermatol. 173 (2), 555-558. doi: 10.1111/bjd.13688

Cheung, Y. K., Cheng, S. H., Chan, E. J., Lo, S. V., Ng, M. H., and Kwan, P. (2013). HLA-B alleles associated with severe cutaneous reactions to antiepileptic drugs in Han Chinese. Epilepsia 54 (7), 1307-1314. doi: 10.1111/epi.12217

Chiu, M. L., Hu, M., Ng, M. H., Yeung, C. K., Chan, J. C., Chang, M. M., et al. (2012). Association between HLA-B ${ }^{\star 58: 01}$ allele and severe cutaneous adverse reactions with allopurinol in Han Chinese in Hong Kong. Br. J. Dermatol. 167 (1), 44-49. doi: 10.1111/j.1365-2133.2012.10894.x
Chong, H. Y., Lim, Y. H., Prawjaeng, J., Tassaneeyakul, W., Mohamed, Z., and Chaiyakunapruk, N. (2018). Cost-effectiveness analysis of HLA-B ${ }^{\star 58}$ : 01 genetic testing before initiation of allopurinol therapy to prevent allopurinolinduced Stevens-Johnson syndrome/toxic epidermal necrolysis in a Malaysian population. Pharmacogenet. Genomics 28 (2), 56-67. doi: 10.1097/ fpc.0000000000000319

Chung, W. H., Hung, S. I., Hong, H. S., Hsih, M. S., Yang, L. C., Ho, H. C., et al. (2004). Medical genetics: a marker for Stevens-Johnson syndrome. Nature 428 (6982), 486. doi: 10.1038/428486a

Chung, W. H., Chang, W. C., Stocker, S. L., Juo, C. G., Graham, G. G., Lee, M. H., et al. (2015). Insights into the poor prognosis of allopurinol-induced severe cutaneous adverse reactions: the impact of renal insufficiency, high plasma levels of oxypurinol and granulysin. Ann. Rheum. Dis. 74 (12), 2157-2164. doi: 10.1136/annrheumdis-2014-205577

Daly, A. K., Donaldson, P. T., Bhatnagar, P., Shen, Y., Pe'er, I., Floratos, A., et al. (2009). HLA-B ${ }^{\star} 5701$ genotype is a major determinant of drug-induced liver injury due to flucloxacillin. Nat. Genet. 41 (7), 816-819. doi: 10.1038/ng.379

Deng, Y. L., Li, S. P., Zhang, L., Jin, H., and Zou, X. Y. (2018). Association between HLA alleles and lamotrigine-induced cutaneous adverse drug reactions in Asian populations: A meta-analysis. Seizure-European J. Epilepsy 60, 163-171. doi: 10.1016/j.seizure.2018.06.024

Elizabeth, J., and Phillips, S. A. M. (2020). “Abacavir hypersensitivity reaction,” in UpToDate. Ed. T. W. Post (Waltham, MA: UpToDate).

Fowler, T., Bansal, A. S., and Lozsadi, D. (2019). Risks and management of antiepileptic drug induced skin reactions in the adult out-patient setting. Seizure 72, 61-70. doi: 10.1016/j.seizure.2019.07.003

Genin, E., Chen, D. P., Hung, S. I., Sekula, P., Schumacher, M., Chang, P. Y., et al. (2014). HLA-A ${ }^{\star 31: 01}$ and different types of carbamazepine-induced severe cutaneous adverse reactions: an international study and meta-analysis. Pharmacogenom. J. 14 (3), 281-288. doi: 10.1038/tpj.2013.40

GlaxoSmithKline. (2009). Lamictal (lamotrigine): full prescribing information (GlaxoSmithKline).

Goncalo, M., Coutinho, I., Teixeira, V., Gameiro, A. R., Brites, M. M., Nunes, R., et al. (2013). HLA-B*58:01 is a risk factor for allopurinol-induced DRESS and Stevens-Johnson syndrome/toxic epidermal necrolysis in a Portuguese population. Br. J. Dermatol. 169 (3), 660-665. doi: 10.1111/bjd.12389

He, N., Min, F. L., Shi, Y. W., Guo, J., Liu, X. R., Li, B. M., et al. (2012). Cutaneous reactions induced by oxcarbazepine in Southern Han Chinese: incidence, features, risk factors and relation to HLA-B alleles. Seizure 21 (8), 614-618. doi: 10.1016/j.seizure.2012.06.014

He, X. J., Jian, L. Y., He, X. L., Wu, Y., Xu, Y. Y., Sun, X. J., et al. (2013). Association between the HLA-B`15:02 allele and carbamazepine-induced Stevens-Johnson syndrome/toxic epidermal necrolysis in Han individuals of northeastern China. Pharmacol. Rep. 65 (5), 1256-1262. doi: 10.1016/S1734-1140(13)71483-X

Hershfield, M. S., Callaghan, J. T., Tassaneeyakul, W., Mushiroda, T., Thorn, C. F., Klein, T. E., et al. (2013). Clinical Pharmacogenetics Implementation Consortium guidelines for human leukocyte antigen-B genotype and allopurinol dosing. Clin. Pharmacol. Ther. 93 (2), 153-158. doi: 10.1038/ clpt.2012.209

Hetherington, S., McGuirk, S., Powell, G., Cutrell, A., Naderer, O., Spreen, B., et al. (2001). Hypersensitivity reactions during therapy with the nucleoside reverse transcriptase inhibitor abacavir. Clin. Ther. 23 (10), 1603-1614. doi: 10.1016/ S0149-2918(01)80132-6

Hetherington, S., Hughes, A. R., Mosteller, M., Shortino, D., Baker, K. L., Spreen, W., et al. (2002). Genetic variations in HLA-B region and hypersensitivity reactions to abacavir. Lancet (London England) 359 (9312), 1121-1122. doi: 10.1016/s0140-6736(02)08158-8

High, W. A. (2020). "Stevens-Johnson syndrome and toxic epidermal necrolysis: Pathogenesis, clinical manifestations, and diagnosis," in UpToDate. Ed. T. W. Post (Waltham, MA: UpToDate).

Hsiao, Y. H., Hui, R. C., Wu, T., Chang, W. C., Hsih, M. S., Yang, C. H., et al (2014). Genotype-phenotype association between HLA and carbamazepineinduced hypersensitivity reactions: strength and clinical correlations. J. Dermatol. Sci. 73 (2), 101-109. doi: 10.1016/j.jdermsci.2013.10.003

Hughes, D. A., Vilar, F. J., Ward, C. C., Alfirevic, A., Park, B. K., and Pirmohamed, M. (2004). Cost-effectiveness analysis of HLA $B^{\star} 5701$ genotyping in preventing abacavir hypersensitivity. Pharmacogenetics 14 (6), 335-342. doi: 10.1097/ 00008571-200406000-00002 
Hung, S. I., Chung, W. H., Liou, L. B., Chu, C. C., Lin, M., Huang, H. P., et al. (2005). HLA-B ${ }^{\star} 5801$ allele as a genetic marker for severe cutaneous adverse reactions caused by allopurinol. Proc. Natl. Acad. Sci. U.S.A. 102 (11), 41344139. doi: 10.1073/pnas.0409500102

Hung, S. I., Chung, W. H., Liu, Z. S., Chen, C. H., Hsih, M. S., Hui, R. C., et al. (2010). Common risk allele in aromatic antiepileptic-drug induced StevensJohnson syndrome and toxic epidermal necrolysis in Han Chinese. Pharmacogenomics 11 (3), 349-356. doi: 10.2217/pgs.09.162

Ihtisham, K., Ramanujam, B., Srivastava, S., Mehra, N. K., Kaur, G., Khanna, N., et al. (2019). Association of cutaneous adverse drug reactions due to antiepileptic drugs with HLA alleles in a North Indian population. Seizure 66, 99-103. doi: 10.1016/j.seizure.2019.02.011

Jung, J. W., Song, W. J., Kim, Y. S., Joo, K. W., Lee, K. W., Kim, S. H., et al. (2011). HLA-B58 can help the clinical decision on starting allopurinol in patients with chronic renal insufficiency. Nephrol. Dial Transplant. 26 (11), 3567-3572. doi: 10.1093/ndt/gfr060

Kang, H. R., Jee, Y. K., Kim, Y. S., Lee, C. H., Jung, J. W., Kim, S. H., et al. (2011). Positive and negative associations of HLA class I alleles with allopurinolinduced SCARs in Koreans. Pharmacogenet. Genomics 21 (5), 303-307. doi: 10.1097/FPC.0b013e32834282b8

Kazeem, G. R., Cox, C., Aponte, J., Messenheimer, J., Brazell, C., Nelsen, A. C., et al. (2009). High-resolution HLA genotyping and severe cutaneous adverse reactions in lamotrigine-treated patients. Pharmacogenet. Genomics 19 (9), 661-665. doi: 10.1097/FPC.0b013e32832c347d

Ke, C. H., Chung, W. H., Tain, Y. L., Huang, Y. B., Wen, Y. H., Chuang, H. Y., et al. (2019). Utility of human leukocyte antigen- ${ }^{\star} 58$ : 01 genotyping and patient outcomes. Pharmacogenet. Genomics 29 (1), 1-8. doi: 10.1097/FPC.0000000000000359

Khor, A. H., Lim, K. S., Tan, C. T., Kwan, Z., Tan, W. C., Wu, D. B., et al. (2017). HLA-A ${ }^{\star} 31$ : 01 and HLA-B ${ }^{\star}$ 15:02 association with Stevens-Johnson syndrome and toxic epidermal necrolysis to carbamazepine in a multiethnic Malaysian population. Pharmacogenet. Genomics 27 (7), 275-278. doi: 10.1097/ FPC.0000000000000287

Khosama, H., Budikayanti, A., Khor, A. H. P., Lim, K. S., Ng, C. C., Mansyur, I. G., et al. (2017). HLA-B ${ }^{\star} 1502$ and carbamazepine induced Stevens-Johnson syndrome/toxic epidermal necrolysis in Indonesia. Neurol. Asia 22 (2), 113116. doi: $10.2217 /$ pgs-2017-0103

Kim, S. H., Lee, K. W., Song, W. J., Kim, S. H., Jee, Y. K., Lee, S. M., et al. (2011). Carbamazepine-induced severe cutaneous adverse reactions and HLA genotypes in Koreans. Epilepsy Res. 97 (1-2), 190-197. doi: 10.1016/ j.eplepsyres.2011.08.010

Koninklijke Nederlandse Maatschappij ter bevordering der Pharmacie (2020a). ABACAVIR HLA -B`5701 2019. (KNMP). Available at: https://kennisbank. $\mathrm{knmp} . \mathrm{nl} /$ article/farmacogenetica/2356.html.

Koninklijke Nederlandse Maatschappij ter bevordering der Pharmacie (2020b). FLUCLOXACILLINE HLA - B*5701 2017. (KNMP). Available at: https:// kennisbank.knmp.nl/article/farmacogenetica/4652.html, updated 2017, November 20.

Koninklijke Nederlandse Maatschappij ter bevordering der Pharmacie (2020c). CARBAMAZEPINE HLA $-B^{*} 1502-A^{*} 3101-B^{\star} 1511$ 2016. (KNMP). Available at: https://kennisbank.knmp.nl/article/farmacogenetica/6237-6238-6239.html, updated 2016, October 31

Koninklijke Nederlandse Maatschappij ter bevordering der Pharmacie (2020d). LAMOTRIGINE HLA - ${ }^{\star} 1502$ 2018. (KNMP). Available at: https:// kennisbank.knmp.nl/article/farmacogenetica/6932.html, updated 2018, May 14.

Koninklijke Nederlandse Maatschappij ter bevordering der Pharmacie (2020e). OXCARBAZEPINE HLA - $B^{\star} 1502$ 2018. (KNMP). Available at: https:// kennisbank.knmp.nl/article/farmacogenetica/6931.html, updated 2018, May 14.

Koninklijke Nederlandse Maatschappij ter bevordering der Pharmacie (2020f). FENYTOINE HLA - $B^{*} 1502$ 2018. (KNMP). Available at: https://kennisbank. knmp.nl/article/farmacogenetica/6927.html, updated 2018, May 14.

Koomdee, N., Pratoomwun, J., Jantararoungtong, T., Theeramoke, V., Tassaneeyakul, W., Klaewsongkram, J., et al. (2017). Association of HLA-A and HLA-B Alleles with Lamotrigine-Induced Cutaneous Adverse Drug Reactions in the Thai Population. Front. Pharmacol. 8, 879. doi: 10.3389/ fphar.2017.00879
Kulkantrakorn, K., Tassaneeyakul, W., Tiamkao, S., Jantararoungtong, T., Prabmechai, N., Vannaprasaht, S., et al. (2012). HLA-B ${ }^{\star} 1502$ strongly predicts carbamazepine-induced Stevens-Johnson syndrome and toxic epidermal necrolysis in Thai patients with neuropathic pain. Pain Pract. 12 (3), 202-208. doi: 10.1111/j.1533-2500.2011.00479.x

Larson, A. M. (2020). “Drug-induced liver injury,” in UpToDate. Ed. K. D. Lindor (Waltham, MA: UpToDate).

Leckband, S. G., Kelsoe, J. R., Dunnenberger, H. M., George, A. L. Jr., Tran, E., Berger, R., et al. (2013). Clinical Pharmacogenetics Implementation Consortium guidelines for HLA-B genotype and carbamazepine dosing. Clin. Pharmacol. Ther. 94 (3), 324-328. doi: 10.1038/clpt.2013.103

Li, L. J., Hu, F. Y., Wu, X. T., An, D. M., Yan, B., and Zhou, D. (2013). Predictive markers for carbamazepine and lamotrigine-induced maculopapular exanthema in Han Chinese. Epilepsy Res. 106 (1-2), 296-300. doi: 10.1016/ j.eplepsyres.2013.05.004

Limkobpaiboon, S., Panomvana Na Ayudhya, D., Dhana, N., and Jongjareanprasert, K. (2010). Prevalence and mortality rate of severe cutaneous adverse reactions at Siriraj hospital. Chula Med. J. 54, $467-477$.

Lin, C. W., Huang, W. I., Chao, P. H., Chen, W. W., and Hsiao, F. Y. (2019). Risk of cutaneous adverse reactions associated with allopurinol or febuxostat in real-world patients: A nationwide study. Int. J. Clin. Pract. 73 (5), e13316. doi: $10.1111 /$ ijcp. 13316

Locharernkul, C., Loplumlert, J., Limotai, C., Korkij, W., Desudchit, T., Tongkobpetch, S., et al. (2008). Carbamazepine and phenytoin induced Stevens-Johnson syndrome is associated with HLA-B ${ }^{*} 1502$ allele in Thai population. Epilepsia 49 (12), 2087-2091. doi: 10.1111/j.15281167.2008.01719.x

Lv, Y. D., Min, F. L., Liao, W. P., He, N., Zeng, T., Ma, D. H., et al. (2013). The association between oxcarbazepine-induced maculopapular eruption and HLA-B alleles in a northern Han Chinese population. BMC Neurol. 13, 75. doi: 10.1186/1471-2377-13-75

Mahar, P. D., Wasiak, J., Hii, B., Cleland, H., Watters, D. A., Gin, D., et al. (2014). A systematic review of the management and outcome of toxic epidermal necrolysis treated in burns centres. Burns J. Int. Soc. Burn Injuries 40 (7), 1245-1254. doi: 10.1016/j.burns.2014.02.006

Mallal, S., Nolan, D., Witt, C., Masel, G., Martin, A. M., Moore, C., et al. (2002). Association between presence of HLA-B ${ }^{\star 5701, ~ H L A-D R 7, ~ a n d ~ H L A-D Q 3 ~ a n d ~}$ hypersensitivity to HIV-1 reverse-transcriptase inhibitor abacavir. Lancet (London England) 359 (9308), 727-732.

Mallal, S., Phillips, E., Carosi, G., Molina, J. M., Workman, C., Tomazic, J., et al. (2008). HLA-B ${ }^{\star} 5701$ screening for hypersensitivity to abacavir. New Engl. J. Med. 358 (6), 568-579. doi: 10.1056/NEJMoa0706135

Martin, A. M., Nolan, D., Gaudieri, S., Almeida, C. A., Nolan, R., James, I., et al. (2004). Predisposition to abacavir hypersensitivity conferred by HLA-B ${ }^{\star} 5701$ and a haplotypic Hsp70-Hom variant. Proc. Natl. Acad. Sci. U. States America 101 (12), 4180-4185. doi: 10.1073/pnas.0307067101

McCabe, A., Santos, E. J., Jones, J., Takeshita, L. Y., Ortega-Rivera, N. D., Del CidPavon, G. M., et al. (2020). Allele frequency net database (AFND) 2020 update: gold-standard data classification oagdanqtG-GF. Nucleic Acid Res. 48, D783D788. doi: 10.1093/nar/gkz1029

McCormack, M., Gui, H., Ingason, A., Speed, D., Wright, G. E. B., Zhang, E. J., et al. (2018). Genetic variation in CFH predicts phenytoin-induced maculopapular exanthema in European-descent patients. Neurology 90 (4), e332-ee41. doi: 10.1212/WNL.0000000000004853

Min, H. K., Lee, B., Kwok, S. K., Ju, J. H., Kim, W. U., Park, Y. M., et al. (2015). Allopurinol hypersensitivity syndrome in patients with hematological malignancies: characteristics and clinical outcomes. Korean J. Intern Med. 30 (4), 521-530. doi: 10.3904/kjim.2015.30.4.521

Mockenhaupt, M. The current understanding of Stevens-Johnson syndrome and toxic epidermal necrolysis. Expert Rev. Clin. Immunol. 20117 (6), 803-813. quiz 14-5. doi: 10.1586/eci.11.66

Mockenhaupt, M. (2020). "Drug reaction with eosinophilia and systemic symptoms (DRESS)," in UpToDate. Ed. T. W. Post (Waltham, MA: UpToDate).

Moon, J., Kim, T. J., Lim, J. A., Sunwoo, J. S., Byun, J. I., Lee, S. T., et al. (2016). HLA-B ${ }^{\star}$ 40:02 and DRB1 ${ }^{\star}$ 04:03 are risk factors for oxcarbazepine-induced maculopapular eruption. Epilepsia 57 (11), 1879-1886. doi: 10.1111/epi.13566 
Mullan, K. A., Anderson, A., Illing, P. T., Kwan, P., Purcell, A. W., and Mifsud, N. A. (2019). HLA-associated antiepileptic drug-induced cutaneous adverse reactions. Hla 93 (6), 417-435. doi: 10.1111/tan.13530

Ng, C. Y., Yeh, Y. T., Wang, C. W., Hung, S. I., Yang, C. H., Chang, Y. C., et al. (2016). Impact of the HLA-B $\left.{ }^{*}\right) 58: 01$ Allele and Renal Impairment on Allopurinol-Induced Cutaneous Adverse Reactions. J. Invest. Dermatol. 136 (7), 1373-1381. doi: 10.1016/j.jid.2016.02.808

Nguyen, D. V., Chu, H. C., Nguyen, D. V., Phan, M. H., Craig, T., Baumgart, K., et al. (2015). HLA-B*1502 and carbamazepine-induced severe cutaneous adverse drug reactions in Vietnamese. Asia Pac. Allergy 5 (2), 68-77. doi: 10.5415/apallergy.2015.5.2.68

Ozeki, T., Mushiroda, T., Yowang, A., Takahashi, A., Kubo, M., Shirakata, Y., et al. (2011). Genome-wide association study identifies HLA-A ${ }^{\star} 3101$ allele as a genetic risk factor for carbamazepine-induced cutaneous adverse drug reactions in Japanese population. Hum. Mol. Genet. 20 (5), 1034-1041. doi: 10.1093/hmg/ddq537

Park, H. W., Kim, D. K., Kim, S. H., Kim, S., Chae, D. W., Yang, M. S., et al. (2019). Efficacy of the HLA-B( ${ }^{*}$ )58:01 Screening Test in Preventing AllopurinolInduced Severe Cutaneous Adverse Reactions in Patients with Chronic Renal Insufficiency-A Prospective Study. J. Allergy Clin. Immunol. Pract. 7 (4), 12711276. doi: 10.1016/j.jaip.2018.12.012

Pfizer. (2016). DILANTIN-125 ${ }^{\circledR}$ (phenytoin) oral suspension [package insert] (New York: Pfizer).

Rauch, A., Nolan, D., Thurnheer, C., Fux, C. A., Cavassini, M., Chave, J. P., et al. (2008). Refining abacavir hypersensitivity diagnoses using a structured clinical assessment and genetic testing in the Swiss HIV Cohort Study. Antiviral Ther. 13 (8), 1019-1028.

Rodriguez-Novoa, S., Garcia-Gasco, P., Blanco, F., Gonzalez-Pardo, G., Castellares, C., Moreno, V., et al. (2007). Value of the HLA-B ${ }^{\star 5701}$ allele to predict abacavir hypersensitivity in Spaniards. AIDS research and human retroviruses. 23 (11), 1374-1376. doi: 10.1111/j.1742-7843.2012.00868.x

Russmann, S., Kaye, J. A., Jick, S. S., and Jick, H. (2005). Risk of cholestatic liver disease associated with flucloxacillin and flucloxacillin prescribing habits in the UK: cohort study using data from the UK General Practice Research Database. Br. J. Clin. Pharmacol. 60 (1), 76-82. doi: 10.1111/j.13652125.2005.02370.x

Saag, M., Balu, R., Phillips, E., Brachman, P., Martorell, C., Burman, W., et al. (2008). High sensitivity of human leukocyte antigen-b*5701 as a marker for immunologically confirmed abacavir hypersensitivity in white and black patients. Clin. Infect. Dis. Off. Publ. Infect. Dis. Soc. America 46 (7), 11111118. doi: $10.1086 / 529382$

Saksit, N., Tassaneeyakul, W., Nakkam, N., Konyoung, P., Khunarkornsiri, U., Chumworathayi, P., et al. (2017). Risk factors of allopurinol-induced severe cutaneous adverse reactions in a Thai population. Pharmacogenet. Genomics 27 (7), 255-263. doi: 10.1097/FPC.0000000000000285

Saokaew, S., Tassaneeyakul, W., Maenthaisong, R., and Chaiyakunapruk, N. (2014). Cost-effectiveness analysis of HLA-B ${ }^{\star} 5801$ testing in preventing allopurinol-induced SJS/TEN in Thai population. PloS One 9 (4), e94294. doi: 10.1371/journal.pone.0094294

Sekula, P., Dunant, A., Mockenhaupt, M., Naldi, L., Bouwes Bavinck, J. N., Halevy, S., et al. (2013). Comprehensive survival analysis of a cohort of patients with Stevens-Johnson syndrome and toxic epidermal necrolysis. J. Invest. Dermatol. 133 (5), 1197-1204. doi: 10.1038/jid.2012.510

Shi, Y. W., Min, F. L., Liu, X. R., Zan, L. X., Gao, M. M., Yu, M. J., et al. (2011). Hla$\mathrm{B}$ alleles and lamotrigine-induced cutaneous adverse drug reactions in the Han Chinese population. Basic Clin. Pharmacol. Toxicol. 109 (1), 42-46. doi: 10.1111/j.1742-7843.2011.00681.x

Shi, Y. W., Min, F. L., Qin, B., Zou, X., Liu, X. R., Gao, M. M., et al. (2012). Association between HLA and Stevens-Johnson syndrome induced by carbamazepine in Southern Han Chinese: genetic markers besides B ${ }^{\star} 1502$ ? Basic Clin. Pharmacol. Toxicol. 111 (1), 58-64. doi: 10.1111/j.17427843.2012.00868.x

Shi, Y. W., Min, F. L., Zhou, D., Qin, B., Wang, J., Hu, F. Y., et al. (2017). HLA$A^{\star 24: 02}$ as a common risk factor for antiepileptic drug-induced cutaneous adverse reactions. Neurology 88 (23), 2183-2191. doi: 10.1212/WNL.00000000 00004008

Stainsby, C. M., Perger, T. M., Vannappagari, V., Mounzer, K. C., Hsu, R. K., Henegar, C. E., et al. (2019). Abacavir Hypersensitivity Reaction Reporting
Rates During a Decade of HLA-B ${ }^{\star 5701}$ Screening as a Risk-Mitigation Measure. Pharmacotherapy 39 (1), 40-54. doi: 10.1002/phar.2196

Steinberg, D. M., Fine, J., and Chappell, R. (2009). Sample size for positive and negative predictive value in diagnostic research using case-control designs. Biostatistics 10 (1), 94-105. doi: 10.1093/biostatistics/kxn018

Sukasem, C., Jantararoungtong, T., Kuntawong, P., Puangpetch, A., Koomdee, N. Satapornpong, P., et al. (2016). HLA-B $\left(^{*}\right.$ ) 58:01 for Allopurinol-Induced Cutaneous Adverse Drug Reactions: Implication for Clinical Interpretation in Thailand. Front. Pharmacol. 7, 186. doi: 10.3389/fphar.2016.00186

Sukasem, C., Chaichan, C., Nakkrut, T., Satapornpong, P., Jaruthamsophon, K., Jantararoungtong, T., et al. (2018). Association between HLA-B Alleles and Carbamazepine-Induced Maculopapular Exanthema and Severe Cutaneous Reactions in Thai Patients. J. Immunol. Res. 2018, 2780272. doi: 10.1155/2018/ 2780272

Swen, J. J., Nijenhuis, M., van Rhenen, M., de Boer-Veger, N. J., Buunk, A. M., Houwink, E. J. F., et al. (2018). Pharmacogenetic Information in Clinical Guidelines: The European Perspective. Clin. Pharmacol. Ther. 103 (5), 795801. doi: 10.1002/cpt.1049

Symonds, W., Cutrell, A., Edwards, M., Steel, H., Spreen, B., Powell, G., et al. (2002). Risk factor analysis of hypersensitivity reactions to abacavir. Clin. Ther. 24 (4), 565-573. doi: 10.1016/S0149-2918(02)85132-3

Tassaneeyakul, W., Jantararoungtong, T., Chen, P., Lin, P. Y., Tiamkao, S., Khunarkornsiri, U., et al. (2009). Strong association between HLA-B ${ }^{\star} 5801$ and allopurinol-induced Stevens-Johnson syndrome and toxic epidermal necrolysis in a Thai population. Pharmacogenet. Genomics 19 (9), 704-709. doi: 10.1097/FPC.0b013e328330a3b8

Tassaneeyakul, W., Tiamkao, S., Jantararoungtong, T., Chen, P., Lin, S. Y., Chen, W. H., et al. (2010). Association between HLA-B*1502 and carbamazepineinduced severe cutaneous adverse drug reactions in a Thai population. Epilepsia 51 (5), 926-930. doi: 10.1111/j.1528-1167.2010.02533.x

Tassaneeyakul, W., Prabmeechai, N., Sukasem, C., Kongpan, T., Konyoung, P., Chumworathayi, P., et al. (2016). Associations between HLA class I and cytochrome P450 2C9 genetic polymorphisms and phenytoin-related severe cutaneous adverse reactions in a Thai population. Pharmacogenet. Genomics 26 (5), 225-234. doi: 10.1097/FPC.0000000000000211

To, S. W., Chen, J. H., Wong, K. H., Chan, K. C., Tsang, O. T., and Yam, W. C. (2013). HLA-B ${ }^{\star} 5701$ genetic screening among HIV-1 infected patients in Hong Kong: is this a practical approach in Han-Chinese? Int. J. STD AIDS 24 (1), 50-52. doi: 10.1258/ijsa.2012.012102

Tonk, E. C. M., Gurwitz, D., Maitland-van der Zee, A. H., and Janssens, A. (2017). Assessment of pharmacogenetic tests: presenting measures of clinical validity and potential population impact in association studies. Pharmacogenom. J. 17 (4), 386-392. doi: 10.1038/tpj.2016.34

ULC MP (2015). Product Monograph Mylan-carbamazepine CR.

US Food and Drug Administration (2009). Official Drug Label: Trileptal (oxcarbazepine). (East Hanover, New Jersey: Novartis Pharmaceuticals Corporation).

Wang, X. Q., Lang, S. Y., Shi, X. B., Tian, H. J., Wang, R. F., and Yang, F. (2010). Cross-reactivity of skin rashes with current antiepileptic drugs in Chinese population. Seizure 19 (9), 562-566. doi: 10.1016/j.seizure.2010.09.003

Wang, Q., Zhou, J. Q., Zhou, L. M., Chen, Z. Y., Fang, Z. Y., Chen, S. D., et al. (2011). Association between HLA-B ${ }^{\star} 1502$ allele and carbamazepine-induced severe cutaneous adverse reactions in Han people of southern China mainland. Seizure 20 (6), 446-448. doi: 10.1016/j.seizure.2011.02.003

Wu, X. T., Hu, F. Y., An, D. M., Yan, B., Jiang, X., Kwan, P., et al. (2010). Association between carbamazepine-induced cutaneous adverse drug reactions and the HLA-B ${ }^{\star} 1502$ allele among patients in central China. Epilepsy Behav. 19 (3), 405-408. doi: 10.1016/j.yebeh.2010.08.007

Yampayon, K., Sukasem, C., Limwongse, C., Chinvarun, Y., Tempark, T., Rerkpattanapipat, T., et al. (2017). Influence of genetic and non-genetic factors on phenytoin-induced severe cutaneous adverse drug reactions. Eur. J. Clin. Pharmacol. 73 (7), 855-865. doi: 10.1007/s00228-017-2250-2

Young, B., Squires, K., Patel, P., Dejesus, E., Bellos, N., Berger, D., et al. (2008). First large, multicenter, open-label study utilizing HLA-B ${ }^{\star} 5701$ screening for abacavir hypersensitivity in North America. AIDS (London England) 22 (13), 1673-1675. doi: 10.1097/QAD.0b013e32830719aa

Youssoufi, F., El Annaz, H., Laraqui, A., Bajjou, T., Hjira, N., Atouf, O., et al. (2017). The prevalence of human leukocyte antigen-B ${ }^{\star 57: 01}$ allele in HIV-1- 
infected Moroccan subjects. Gene Rep. 9, 108-110. doi: 10.1016/ j.genrep.2017.09.007

Zeng, T., Long, Y. S., Min, F. L., Liao, W. P., and Shi, Y. W. (2015). Association of HLA-B ${ }^{\star} 1502$ allele with lamotrigine-induced Stevens-Johnson syndrome and toxic epidermal necrolysis in Han Chinese subjects: a meta-analysis. Int. J. Dermatol. 54 (4), 488-493. doi: 10.1111/ijd.12570

Zhang, H., Zhang, T., Zhao, H., Han, N., Zhou, H., He, Y., et al. (2015). Low prevalence of human leukocyte antigen-B ${ }^{\star} 5701$ in HIV-1-infected Chinese subjects: a prospective epidemiological investigation. AIDS Res. Ther. 12, 28. doi: 10.1186/s12981-015-0064-9

Zhang, X., Ma, H., Hu, C., Yu, B., Ma, W., Wu, Z., et al. (2015). Detection of HLA$B \star 58: 01$ with TaqMan assay and its association with allopurinol-induced sCADR. Clin. Chem. Lab. Med. 53 (3), 383-390. doi: 10.1515/cclm-2014-0251
Conflict of Interest: The authors declare that the research was conducted in the absence of any commercial or financial relationships that could be construed as a potential conflict of interest.

The reviewer UA declared a past collaboration with one of the authors JS to the handling editor.

Copyright (C) 2020 Manson, Swen and Guchelaar. This is an open-access article distributed under the terms of the Creative Commons Attribution License (CC BY). The use, distribution or reproduction in other forums is permitted, provided the original author(s) and the copyright owner(s) are credited and that the original publication in this journal is cited, in accordance with accepted academic practice. No use, distribution or reproduction is permitted which does not comply with these terms. 